NBER WORKING PAPER SERIES

THE FINANCING OF R\&D AND INNOVATION

\author{
Bronwyn H. Hall \\ Josh Lerner \\ Working Paper 15325 \\ http://www.nber.org/papers/w15325 \\ NATIONAL BUREAU OF ECONOMIC RESEARCH \\ 1050 Massachusetts Avenue \\ Cambridge, MA 02138 \\ September 2009
}

Forthcoming 2010 in Hall, B. H. and N. Rosenberg (eds.), Handbook of the Economics of Innovation, Elsevier-North Holland. We are grateful to Bruce Petersen for a careful reading of the manuscript. The second author thanks the Harvard Business School's Division of Research for financial support. This chapter is based on material in Hall (2002) and Gompers and Lerner (2004). The views expressed herein are those of the author(s) and do not necessarily reflect the views of the National Bureau of Economic Research.

NBER working papers are circulated for discussion and comment purposes. They have not been peerreviewed or been subject to the review by the NBER Board of Directors that accompanies official NBER publications.

(C) 2009 by Bronwyn H. Hall and Josh Lerner. All rights reserved. Short sections of text, not to exceed two paragraphs, may be quoted without explicit permission provided that full credit, including $\odot$ notice, is given to the source. 
The Financing of R\&D and Innovation

Bronwyn H. Hall and Josh Lerner

NBER Working Paper No. 15325

September 2009

JEL No. G24,G32,O32,O38

\begin{abstract}
$\underline{\text { ABSTRACT }}$
Evidence on the "funding gap" for investment innovation is surveyed. The focus is on financial market reasons for underinvestment that exist even when externality-induced underinvestment is absent. We conclude that while small and new innovative firms experience high costs of capital that are only partly mitigated by the presence of venture capital, the evidence for high costs of R\&D capital for large firms is mixed. Nevertheless, large established firms do appear to prefer internal funds for financing such investments and they manage their cash flow to ensure this. Evidence shows that there are limits to venture capital as a solution to the funding gap, especially in countries where public equity markets for VC exit are not highly developed. We conclude by suggesting areas for further research.
\end{abstract}

Bronwyn H. Hall

Dept. of Economics

549 Evans Hall

UC Berkeley

Berkeley, CA 94720-3880

and NBER

bhhall@nber.org

Josh Lerner

Harvard Business School

Rock Center 214

Boston, MA 02163

and NBER

jlerner@hbs.edu 
1. INTRODUCTION

2. RESEARCH AND DEVELOPMENT AS INVESTMENT ....................................................................5

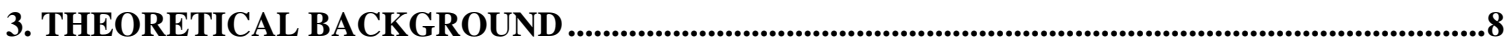

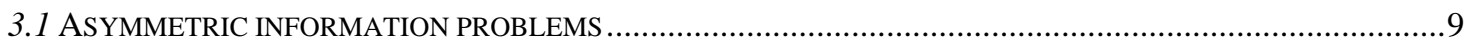

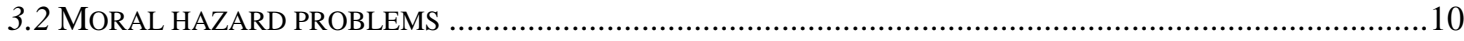

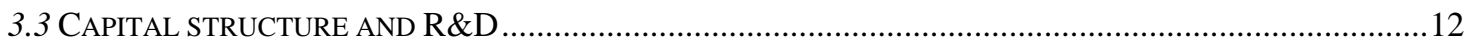

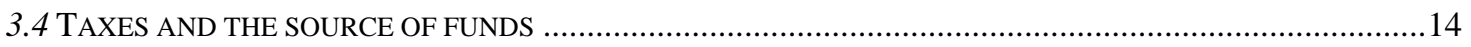

4. TESTING FOR FINANCIAL CONSTRAINTS.....................................................................................16

5. SMALL FIRMS, STARTUP FINANCE, AND VENTURE CAPITAL ............................................24

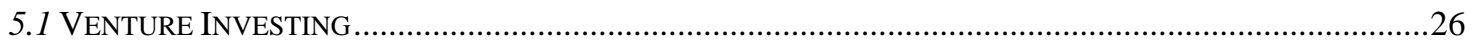

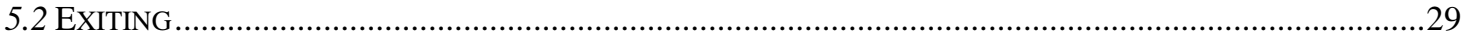

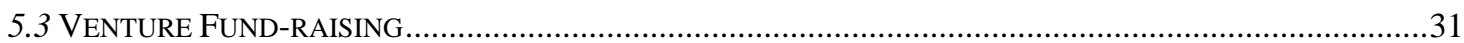

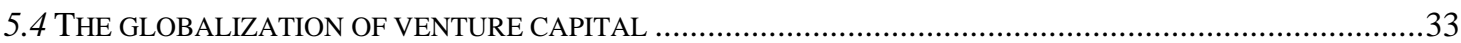

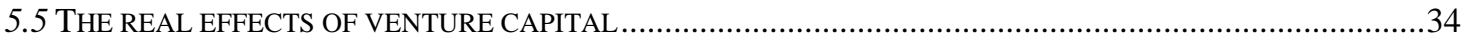

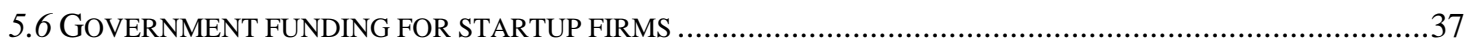

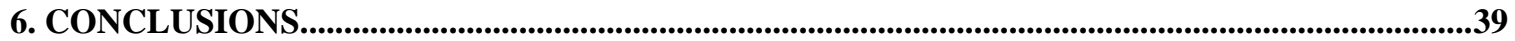




\title{
The Financing of R\&D and Innovation
}

\author{
Bronwyn H. Hall and Josh Lerner
}

\section{Introduction}

It is a widely held view that research and development (R\&D) and innovative activities are difficult to finance in a freely competitive market place. Support for this view in the form of economic-theoretic modeling is not difficult to find and probably begins with the classic articles of Nelson (1959) and Arrow (1962), although the idea itself was alluded to by Schumpeter (1942). ${ }^{1}$ The main argument goes as follows: the primary output of resources devoted to invention is the knowledge of how to make new goods and services, and this knowledge is nonrival: use by one firm does not preclude its use by another. To the extent that knowledge cannot be kept secret, the returns to the investment in knowledge cannot be appropriated by the firm undertaking the investment, and therefore such firms will be reluctant to invest, leading to the underprovision of $\mathrm{R} \& \mathrm{D}$ investment in the economy.

Since the time when this argument was fully articulated by Arrow, it has of course been developed, tested, modified, and extended in many ways. For example, Levin et al (1987) and Mansfield et al (1981), using survey evidence, found that imitating a new invention in a manufacturing firm was not free, but could cost as much as fifty to seventy-five per cent of the cost of the original invention. This fact will mitigate but not eliminate the underinvestment problem. Empirical support for the basic point made by Arrow concerning the positive externalities created by research is widespread, mostly in the form of studies that document a social return to R\&D that

\footnotetext{
${ }^{1}$ See, for example, footnote 1, Chapter VIII of Capitalism, Socialism and Democracy.
} 
is higher than the private level (Griliches, 1992; Hall, 1996). Recently, a large number of authors led by Romer (1986) have produced models of endogenous macro-economic growth that are built on the increasing returns principle implied by Arrow's argument that one person's use of knowledge does not diminish its utility to another (Aghion and Howitt, 1997).

This line of reasoning is already widely used by policymakers to justify such interventions as the intellectual property system, government support of $\mathrm{R} \& \mathrm{D}, \mathrm{R} \& \mathrm{D}$ tax incentives, and the encouragement of research partnerships of various kinds. In general, these incentive programs can be warranted even when the firm or individual undertaking the research is the same as the entity that finances it. However, Arrow's influential paper also contains another reason for underinvestment in R\&D, again one which was foreshadowed by Schumpeter and which has been addressed by subsequent researchers in economics and finance: the argument that an additional gap exists between the private rate of return and the cost of capital when the innovation investor and financier are different entities.

This chapter concerns itself with this second aspect of the market failure for R\&D and other investments in innovation: even if problems associated with incomplete appropriability of the returns to $\mathrm{R} \& \mathrm{D}$ are solved using intellectual property protection, subsidies, or tax incentives, it may still be difficult or costly to finance such investments using capital from sources external to the firm or entrepreneur. That is, there is often a wedge, sometimes large, between the rate of return required by an entrepreneur investing his own funds and that required by external investors. By this argument, unless an inventor is already wealthy, or firms already profitable, some innovations will fail to be provided purely because the cost of external capital is too high, even when they would pass the private returns hurdle if funds were available at a "normal" interest rate.

In the following, we begin by describing some of the unique features of $\mathrm{R} \& \mathrm{D}$ investment. Then we discuss the various theoretical arguments why external finance for R\&D might be more 
expensive that internal finance, going on to review the empirical evidence on the validity of this hypothesis and the solutions that have been developed and adopted by the market and some governments, in particular the venture capital solution. Although we focus our attention on R\&D in the first three sections of the paper, much of what we discuss will apply to innovation investment more broadly defined. However, for reasons of data availibility and measurement the empirical literature has largely focused on R\&D spending, at least up until now. The chapter concludes with a discussion of policy options.

\section{Research and development as investment}

From the perspective of investment theory, R\&D has a number of characteristics that make it different from ordinary investment. First and most importantly, in practice fifty per cent or more of R\&D spending is the wages and salaries of highly educated scientists and engineers. Their efforts create an intangible asset, the firm's knowledge base, from which profits in future years will be generated. To the extent that this knowledge is "tacit" rather than codified, it is embedded in the human capital of the firm's employees, and is therefore lost if they leave or are fired.

This fact has an important implication for the conduct of R\&D investment. Because part of the resource base of the firm itself disappears when such workers leave or are fired and because projects often take a long time between conception and commercialization, firms tend to smooth their R\&D spending over time, in order to avoid having to lay off knowledge workers. This implies that R\&D spending at the firm level usually behaves as though it has high adjustment costs (Hall, Griliches, and Hausman, 1986; Lach and Schankerman, 1988), with two consequences, one substantive and one that affects empirical work in this area. First, the equilibrium required rate of return to R\&D may be quite high simply to cover the adjustment costs. Second, and related to the first, is that it will be difficult to measure the impact of changes in the costs of capital, because such 
effects can be weak in the short run due to the sluggish response of R\&D to any changes in its cost. J. Brown and Petersen (2009) offer direct evidence that U. S. firms relied heavily on cash reserves to smooth R\&D spending during the 1998-2002 boom and bust in stock market returns.

A second important feature of $\mathrm{R} \& \mathrm{D}$ investment is the degree of uncertainty associated with its output. This uncertainty tends to be greatest at the beginning of a research program or project, which implies that an optimal R\&D strategy has an options-like character and should not really be analyzed in a static framework. $R \& D$ projects with small probabilities of great success in the future may be worth continuing even if they do not pass an expected rate of return test. The uncertainty here can be extreme and not a simple matter of a well-specified distribution with a mean and variance. There is evidence, such as that in Scherer (1998), that the distribution of profits from innovation sometimes has a Paretian character where the variance does not exist. When this is the case, standard risk-adjustment methods will not work well.

In spite of the problems suggested by the nature of uncertainty in this area, the starting point for the analysis of R\&D investment financing has been the "neo-classical" marginal profit condition, suitably modified to take the special features of R\&D into account. Following the formulation in Hall and Van Reenen (2000), we define the user cost of R\&D investment $\varrho$ as the pre-tax real rate of return on a marginal investment that is required to earn a return $\mathrm{r}$ after (corporate) tax. The firm invests to the point where the marginal product of R\&D capital equals $\varrho$ :

$$
M P K=\rho=\frac{1-A^{d}-A^{c}}{1-\tau}\left(r+\delta-\Delta p_{R} / p_{R}+M A C\right)
$$

$\tau$ is the corporate tax rate, $\delta$ is the (economic) depreciation rate, the term in $p_{R}$ is the relative appreciation or depreciation of $\mathrm{R} \& \mathrm{D}$ capital, and $M A C$ is the marginal adjustment cost.

In this equation, $A^{d}$ and $A^{c}$ are the present discounted value of deprecation allowances and tax credits respectively. In most financial accounting systems, including those used by major OECD 
economies, R\&D is expensed as it is incurred rather than capitalized and depreciated, which means that the lifetime of the investment for accounting purposes is much shorter than the economic life of the asset created and that $A^{d}$ is simply equal to $\tau$ for tax-paying firms. Many countries have a form of tax credit for R\&D, either incremental or otherwise, and this will be reflected in a positive value for $A^{c}{ }^{2}$ Note that when $A^{c}$ is zero, the corporate tax rate does not enter into the marginal $\mathrm{R} \& \mathrm{D}$ decision, because of the full deductability of R\&D.

The user cost formulation above directs attention to the following determinants of $\mathrm{R} \& \mathrm{D}$ financing:

1. tax treatment such as tax credits, which are clearly amenable to intervention by policy makers.

2. economic depreciation $\delta$, which in the case of R\&D is more properly termed obsolesence. This quantity is sensitive to the realized rate of technical change in the industry, which is in turn determined by such things as competition, market structure and the rate of imitation. Thus it is inappropriate to treat $\delta$ as an invariant parameter in this setting.

3. the marginal costs of adjusting the level of the R\&D program.

4. the investor's required rate of return $r$.

The last item has been the subject of considerable theoretical and empirical interest, on the part of both industrial organization and corporate finance economists. Two broad strands of investigation can be observed: one focuses on the role of asymmetric information and moral hazard in raising the required rate of return abve that normally used for conventional investment, and the latter on the requirements of different sources of financing and their differing tax treatments for the rate of return. The next section of the paper discusses these factors.

2 See Hall and Van Reenen (2000) for details. For example, during the past three decades the US has had an incremental $\mathrm{R} \& \mathrm{D}$ tax credit with a value for $A^{c}$ of about 0.13 at the time of writing. 


\section{Theoretical background}

This section of the paper reviews the reasons that the impact of financial considerations on the investment decision may vary with the type of investment and with the source of funds in more detail. To do this, we distinguish between those factors that arise from various kinds of market failures in this setting and the purely financial (or tax-oriented) considerations that affect the cost of different sources of funds.

One of the implications of the well-known Modigliani-Miller theorem $(1958,1961)$ is that a firm choosing the optimal levels of investment should be indifferent to its capital structure, and should face the same price for investment and R\&D investment on the margin. The last dollar spent on each type of investment should yield the same expected rate of return (after adjustment for nondiversifiable risk). A large literature, both theoretical and empirical, has questioned the bases for this theorem, but it remains a useful starting point.

Reasons why the theorem might fail in practice are several: 1) uncertainty coupled with incomplete markets may make a real options approach to the $R \& D$ investment decision more appropriate; 2) the cost of capital may differ by source of funds for non-tax reasons; 3) the cost of capital may differ by source of funds for tax reasons; and 4) the cost of capital may also differ across types of investments (tangible and intangible) for both tax and other reasons.

With respect to $R \& D$ investment, economic theory advances a plethora of reasons why there might be a gap between the external and internal costs of capital; these can be divided into three main types:

1. Asymmetric information between inventor/entrepreneur and investor.

2. Moral hazard on the part of the inventor/entrepreneur arising from the separation of ownership and management. 
3. Tax considerations that drive a wedge between external finance and finance by retained earnings.

We discuss each of these reasons in separate sections below.

\subsection{Asymmetric information problems}

In the innovation setting, the asymmetric information problem refers to the fact that an inventor frequently has better information about the likelihood of success and the nature of the contemplated innovation project than potential investors. Therefore, the marketplace for financing the development of innovative ideas looks like the "lemons" market modeled by Akerlof (1970). The lemons' premium for R\&D will be higher than that for ordinary investment because investors have more difficulty distinguishing good projects from bad when the projects are long-term $\mathrm{R} \& \mathrm{D}$ investments than when they are more short-term or low-risk projects (Leland and Pyle, 1977). When the level of R\&D expenditure is a highly observable signal, as it is under current U.S. and U.K. rules, we might expect that the lemons' problem is somewhat mitigated, but certainly not eliminated. ${ }^{3}$

In the most extreme version of the lemons model, the market for R\&D projects may disappear entirely if the asymmetric information problem is too great. Informal evidence suggests that some potential innovators believe this to be the case in fact. And as will be discussed below, venture capital systems are viewed by some as a solution to this "missing markets" problem.

Reducing information asymmetry via fuller disclosure is of limited effectiveness in this arena, due to the ease of imitation of inventive ideas. Firms are reluctant to reveal their innovative ideas to the marketplace and the fact that there could be a substantial cost to revealing information to their competitors reduces the quality of the signal they can make about a potential project (Bhattacharya

\footnotetext{
${ }^{3}$ Since 1974, publicly traded firms in the United States have been required to report their total R\&D expenditures in their annual reports and 10-K filings with the SEC, under FASB rule No. 2, issued October 1974. In 1989, a new accounting standard, SSAP 13, obligated similar disclosures in the UK. Most continental European countries have not had such a requirement in the past, but this is changing as hamonized international standards come into force. JAPAN
} 
and Ritter, 1983; Anton and Yao, 1998). Thus the implication of asymmetric information coupled with the costliness of mitigating the problem is that firms and inventors will face a higher cost of external than internal capital for R\&D due to the lemons’ premium.

Some empirical support for this proposition exists, mostly in the form of event studies that measure the market response to announcements of new debt or share issues. ${ }^{4}$ Both Alam and Walton (1995) and Zantout (1997) find higher abnormal returns to firm shares following new debt issues when the firm is more R\&D-intensive. The argument is that the acquisition of new sources of financing is good news when the firm has an asymmetric information problem because of its R\&D strategy. Similary, Szewcxyk, Tsetsekos, and Zantout (1996) find that investment opportunities (as proxied by Tobin's q) explain R\&D-associated abnormal returns, and that these returns are higher when the firm is highly leveraged, implying a higher required rate of return for debt finance in equilibrium.

\subsection{Moral hazard problems}

Moral hazard in R\&D investing arises in the usual way: modern industrial firms normally have separation of ownership and management. This leads to a principal-agent problem when the goals of the two conflict, which can result in investment strategies that are not share value maximizing. Two possible scenarios may co-exist: one is the usual tendency of managers to spend on activities that benefit them (growing the firm beyond efficient scale, nicer offices, etc.) and the second is a reluctance of risk averse managers to invest in uncertain R\&D projects. Agency costs of the first type may be avoided by reducing the amount of free cash flow available to the managers by leveraging the firm, but this in turn forces them to use the higher cost external funds to finance

${ }^{4}$ See Campbell, Lo, and McKinlay (1997) for a descripion of this methodology, which infers the value of a firm's action when it is publicly announced by examining the market returns to a share of the firm's stock in the period surrounding the announcement. 
R\&D (Jensen and Meckling, 1976). Empirically, there seem to be limits to the use of the leveraging strategy in R\&D-intensive sectors. See Hall $(1990,1994)$ for evidence that the LBO/restructuring wave of the 1980s was almost entirely confined to industries and firms where R\&D was of no consequence. As we discuss in the next section, it is still true that R\&D-intensive firms tend to have lower leverage than other firms on average.

According to the second type of principal-agent conflict, managers are more risk averse than shareholders and avoid R\&D projects that will increase the riskiness of the firm. If bankruptcy is a possibility, both managers whose opportunity cost is lower than their present earnings and potential bondholders may wish to avoid variance-increasing projects which shareholders would like to undertake. The argument of the theory is that long-term investments can suffer in this case. The optimal solution to this type of agency cost would be to increase the long-term incentives faced by the manager rather than reducing free cash flow.

Evidence on the importance of agency costs as they relate to $\mathrm{R} \& \mathrm{D}$ takes several forms. Several researchers have studied the impact of antitakeover amendments (which arguably increase managerial security and willingness to take on risk while reducing managerial discipline) on $\mathrm{R} \& \mathrm{D}$ investment and firm value. Johnson and Rao (1997) find that such amendments are not followed by cuts in R\&D, while Pugh, Jahara, and Oswald (1999) find that adoption of an Employee Stock Ownership Plan (ESOP), which is a form of antitakeover protection, is followed by R\&D increases. Cho (1992) finds that R\&D intensity increases with the share that managerial shareholdings represent of the manager's wealth and interprets this as incentive pay mitigating agency costs and inducing long term investment.

Some have argued that institutional ownership of the managerial firm can reduce the agency costs due to free-riding by owners that is a feature of the governance of firms with diffuse ownership structure, while others have held that such ownership pays too much attention to short 
term earnings and therefore discourages long term investments. Institutions such as mutual and pension funds often control somewhat larger blocks of shares than individuals, making monitoring firm and manager behavior a more effective and more rewarding activity for these organizations.

There is some limited evidence that this may indeed be the case. Eng and Shackell (2001) find that firms adopting long term performance plans for their managers do not increase their R\&D spending but that institutional ownership is associated with higher R\&D; R\&D firms tend not to be held by banks and insurance companies. Majumdar and Nagarajan (1997) find that high institutional investor ownership does not lead to short-term behavior on the part of the firm, in particular, it does not lead to cuts in R\&D spending. Francis and Smith (1995) find that diffusely held firms are less innovative, implying that monitoring alleviates agency costs and enables investment in innovation.

Although the evidence summarized above is fairly clear and indicates that long term incentives for managers can encourage $R \& D$ and that institutional ownership does not necessarily discourage $R \& D$ investment, it is fairly silent on the magnitude of these effects, and whether these governance features truly close the agency cost-induced gap between the cost of capital and the return to $\mathrm{R} \& \mathrm{D}$.

\subsection{Capital structure and $R \& D$}

In the view of some observers, the leveraged buyout (LBO) wave of the 1980s in the United States and the United Kingdom arose partly because high real interest rates meant that there were strong pressures to eliminate free cash flow within firms (Blair and Litan, 1990). For firms in industries where $\mathrm{R} \& \mathrm{D}$ is an important form of investment, such pressure should have been reduced by the need for internal funds to undertake such investment and indeed Hall $(1993,1994)$ and Opler and Titman (1993) find that firms with high R\&D intensity were much less likely to experience an 
LBO. Opler and Titman (1994) find that R\&D firms that were leveraged suffered more than other firms when facing economic distress, presumably because leverage meant that they were unable to sustain R\&D programs in the fact of reduced cash flow.

A more recent look at the consequences of these transactions is by Lerner et al. (2008). The authors investigate 495 buyout transactions where there was a patent application in the nine years around the buyout. They find no evidence that LBOs are associated with a decrease in patenting. Relying on standard measures of patent quality, they find that patents granted to firms involved in private equity transactions are more cited (a proxy for economic importance), show no significant shifts in the fundamental nature of the research, and are more concentrated in the most important and prominent areas of companies' innovative portfolios, suggesting a refocusing on the core business, but not a reduction in innovative activity..

In related work using data on Israeli firms, Blass and Yosha (2001) report that R\&Dintensive firms listed on the United States stock exchanges use highly equity-based sources of financing, whereas those listed only in Israel rely more on bank financing and government funding. The former are more profitable and faster-growing, which suggests that the choice of where to list the shares and whether to finance with new equity is indeed sensitive to the expected rate of return to the $\mathrm{R} \& \mathrm{D}$ being undertaken. That is, investors supplying arms-length finance require higher returns to compensate them for the risk of a "lemon."

Although leverage may be a useful tool for reducing agency costs in the firm, it is of limited value for R\&D-intensive firms. Because the knowledge asset created by R\&D investment is intangible, partly embedded in human capital, and ordinarily very specialized to the particular firm in which it resides, the capital structure of R\&D-intensive firms customarily exhibits considerably less leverage than that of other firms. Banks and other debtholders prefer to use physical assets to secure loans and are reluctant to lend when the project involves substantial R\&D investment rather than 
investment in plant and equipment. In the words of Williamson (1988), "redeployable" assets (that is, assets whose value in an alternative use is almost as high as in their current use) are more suited to the governance structures associated with debt. Empirical support for this idea is provided by Alderson and Betker (1996), who find that liquidation costs and R\&D are positively related across firms. The implication is that the sunk costs associated with R\&D investment are higher than that for ordinary investment.

In addition, servicing debt usually requires a stable source of cash flow, which makes it more difficult to find the funds for an R\&D investment program that must be sustained at a certain level in order to be productive. For both these reasons, firms are either unable or reluctant to use debt finance for R\&D investment, which may raise the cost of capital, depending on the precise tax treatment of debt versus equity. ${ }^{5}$ Confirming empirical evidence for the idea that limiting free cash flow in R\&D firms is a less desirable method of reducing agency costs is provided by Chung and Wright (1998), who find that financial slack and R\&D spending are correlated with the value of growth firms positively, but not correlated with that of other firms.

\subsection{Taxes and the source of funds}

Tax considerations that yield variations in the cost of capital across source of finance have been well articulated by Auerbach (1984) among others. He argued that under the U.S. tax system during most of its history the cost of financing new investment by debt has been less that of financing it by retained earnings, which is in turn less than that of issuing new shares. More explicitly, if $r$ is the risk-adjusted required return to capital, $\tau$ is the corporate tax rate, $\theta$ is the personal tax rate, and $c$ is the capital gains tax rate, we have the following required rates of return for different financing sources:

\footnotetext{
5 There is also considerable cross-sectional evidence for the United States that R\&D intensity and leverage are negatively correlated across firms. See Friend and Lang (1988), Hall (1992), and Bhagat and Welch (1995).
} 
Debt $\quad r(1-\tau) \quad$ interest deductible at the corporate level

Retained earnings $\quad r(1-\theta) /(1-c) \quad$ avoids personal tax on dividends, but capital gains tax

New shares $\quad r /(1-c) \quad$ eventual capital gains tax

If dividends are taxed, clearly financing with new shares is more expensive than financing with retained earnings. And unless the personal income tax rate is much higher than the sum of the corporate and capital gains rates, the following inequalities will both hold:

$$
(1-\tau)<\frac{1-\theta}{1-c}<\frac{1}{1-c}
$$

These inequalities express the facts that interest expense is deductible at the corporate level, while dividend payments are not, and that shareholders normally pay tax at a higher rate on retained earnings that are paid out than on those retained by the firm and invested. ${ }^{6}$ It implicitly assumes that the returns from the investment made will be retained by the firm and eventually taxed at the capital gains rate rather than the rate on ordinary income.

It is also true that the tax treatment of $R \& D$ in most OECD economies is very different from that of other kinds of investment: because $\mathrm{R} \& \mathrm{D}$ is expensed as it is incurred, the effective tax rate on $\mathrm{R} \& \mathrm{D}$ assets is lower than that on either plant or equipment, with or without an $\mathrm{R} \& \mathrm{D} \operatorname{tax}$ credit in place. This effectively means that the economic depreciation of R\&D assets is considerably less than the depreciation allowed for tax purposes -- which is 100 percent -- so that the required rate of return for such investment would be lower. In addition some countries offer a tax credit or subsidy to R\&D spending, which can reduce the after tax cost of capital even further. ${ }^{7}$

\footnotetext{
${ }^{6}$ A detailed discussion of tax regimes in different countries is beyond the scope of this survey, but it is quite a common in several countries for long term capital gains on funds that remain with a firm for more than one year to be taxed at a lower rate than ordinary income. Of course, even if the tax rates on the two kinds of income are equal, the inequalities will hold. Only in the case where dividends are not taxed at the corporate level (which was formerly the case in the UK) will the ranking given above not hold.

${ }^{7}$ See Hall and Van Reenen (2000) for details.
} 
The conclusion from this section of the paper is that the presence of either asymmetric information or a principal-agent conflict imply that new debt or equity finance will be relatively more expensive for $\mathrm{R} \& \mathrm{D}$ than for ordinary investment, and that considerations such as lack of collateral further reduce the possibility of debt finance. Together, these arguments suggest an important role for retained earnings in the R\&D investment decision, independent of their value as a signal of future profitability. In fact, as has been argued by both Hall (1992) and Himmelberg and Petersen (1994), there is good reason to think that positive cash flow may be more important for $\mathrm{R} \& \mathrm{D}$ than for ordinary investment. The next section summarizes the results from empirical tests for this proposition.

\section{Testing for financial constraints}

The usual way to examine the empirical relevance of the arguments that R\&D investment in established firms can be disadvantaged when internal funds are not available and recourse to external capital markets required is to estimate R\&D investment equations and test for the presence of "liquidity" constraints, or excess sensitivity to cash flow shocks. This approach builds on the extensive literature developed for testing ordinary investment equations for liquidity constraints (Fazzari, Hubbard, and Petersen, 1988; Arellano and Bond, 1991). It suffers from many of the same difficulties as the estimates in the investment literature, plus one additional problem that arises from the tendency of firms to smooth R\&D spending over time.

The ideal experiment for identifying the effects of liquidity constraints on investment is to give firms additional cash exogenously, and observe whether they pass it on to shareholders or use it for investment and/or R\&D. If they choose the first alternative, either the cost of capital to the firm has not fallen, or it has fallen but they still have no good investment opportunities. If they choose the second, then the firm must have had some unexploited investment opportunities that were not 
profitable using more costly external finance. A finding that investment is sensitive to cash flow shocks that are not signals of future demand increases would reject the hypothesis that the cost of external funds is the same as the cost of internal funds. However, lack of true experiments of this kind forces researchers to use econometric techniques such as instrumental variables to attempt to control for demand shocks when estimating the investment demand equation, with varying degrees of success.

The methodology for the identification of $\mathrm{R} \& \mathrm{D}$ investment equations is based on a simple supply and demand heuristic, as shown in Figure 1. The curve sloping downward to the right represents the demand for R\&D investment funds and the curves sloping upward the supply of funds. Internal funds are available at a constant cost of capital until they are exhausted, at which point it becomes necessary to issue debt or equity in order to finance more investment. When the demand curve cuts the supply curve in the horizontal portion, a shock that increases cash flow (and shifts supply outward) has no effect on the level of investment. However, if the demand curve cuts the supply curve where it is upward sloping, it is possible for a shock to cash flow to shift the supply curve out in such a way as to induce a substantial increase in R\&D investment. Figure 2 illustrates such a case, where the firm shifts from point $A$ to point $B$ in response to a cash flow shock that does not shift the demand curve.

Econometric work that tests the hypothesis that financing constraints matter for $\mathrm{R} \& \mathrm{D}$ investment has largely been done using standard investment equation methodology. Two main approaches can be identified: one uses a neoclassical accelerator model with ad hoc dynamics to allow for the presence of adjustment costs, and the other an Euler equation derived from the 
forward-looking dynamic program of a profit-maximizing firm that faces adjustment costs for capital. $^{8}$

The accelerator model begins with the marginal product equal to cost condition for capital:

$$
M P K=C
$$

Assuming that the production function for the $i$ th firm at time $t$ is Cobb-Douglas, solving out the variable factors, and taking logarithms of this relationship yields

$$
k_{i t}=s_{i t}+a_{i}-c_{i t}
$$

where $k=\log \left(\mathrm{R} \& \mathrm{D}\right.$ capital), $s=\log$ (output or sales), and $c=\log (\operatorname{cost}$ of $\mathrm{R} \& \mathrm{D}) \cdot a_{i}$ captures any permanent differences across firms, including differences in the production function.

Lagged adjustment of $\mathrm{R} \& \mathrm{D}$ capital to changes in its cost or expected future demand is allowed for by specifying an autoregressive distributed lag (ADL) for the relationship between capital and sales. For example, specifying an $\operatorname{ADL}(2,2)$ and approximating the growth of the capital stock $\Delta k$ by $R / K-\delta$ yields an estimating equation of the following form:

$$
\frac{R}{K}=f\left(\frac{R(-1)}{K(-1)}, \Delta s, \Delta s(-1), k(-2)-s(-2), \text { time dummies, firm dummies }\right)
$$

The time dummies capture the conventional cost of capital, assumed to be the same for all firms. Note that any variations in $\mathrm{R} \& \mathrm{D}$ capital depreciation common to all firms will be in the time dummies, and any variations specific to a firm or sector but constant over time will be in the firm dummies. Firm-specific costs related to financing constraints are included by adding current and lagged values of the cash flow/capital ratio to this equation. Because of the presence of firm dummies, estimation is done using first differences of this equation, instrumented by lagged values of the right hand side variables to correct for the potential endogeneity of the contemporaneous

8 A detailed consideration of the econometric estimation of these models can be found in Mairesse, Hall, and Mulkay (1999). See also Hall (1981). 
values. In principle, this will also control for the potential simultaneity between current investment and the disturbance. However, if the firm's planning horizon for its R\&D programs is long enough, as we might expect in the biotechnology area, for example, we might be concerned about the validity of lagged instruments.

The Euler equation approach begins with the following first order condition for investment in two adjacent periods:

$$
E_{t-1}\left[M P K_{t}+(1-\delta)\left(p_{t}+M A C_{t}\right)-(1+r)\left(\frac{\alpha_{t-1}}{\alpha_{t}}\right)\left(p_{t-1}+M A C_{t-1}\right)\right]=0
$$

where $M A C$ denotes the marginal adjustment costs for $\mathrm{R} \& \mathrm{D}$ capital and $a_{t}$ is the shadow value of investment funds in period $t$, which will be unity if there are no financing constraints. After specifying a Cobb-Douglas production function and quadratic adjustment costs, we obtain the following estimating equation:

$$
E\left[\frac{R}{K}-\beta_{1} \frac{R(-1)}{K(-1)}-\gamma_{1} \frac{S}{K}-\beta_{2}\left(\frac{R}{K}\right)^{2} \text { - time dummies - firm dummies } \mid Z\right]=0
$$

where $\mathrm{Z}$ is a set of appropriate instrumental variables. As in the case of the accelerator model, this equation is usually estimated in differenced form to remove the firm dummies, with lagged values of the right hand side variables as instruments.

When financial constraints are present, the coefficient of lagged $R \& D$ investment in the Euler equation differs from $(1+r)$ by the term $\left(a_{t-1} / a_{t}\right)$. The implication is that when the firm changes its financial position (that is, the shadow value of additional funds for investment changes) between one period and the next, it will invest as though it is facing a cost of capital greater than $r$ (when the shadow value falls between periods) or less than $r$ (when the shadow value rises between periods). Clearly this is a very difficult test to perform because $\left(a_{t-1} / a_{t}\right)$ is not constant across firms or across time periods, so it cannot be treated as a parameter. 
Three solutions are possible: the first is to model $\left(a_{t-1} / a_{t}\right)$ as a function of proxies for changes in financial position, such as dividend behavior, new share issues, or new debt issues. The second is more ad hoc: recall that this term also multiplies the price $p_{t}$ of $\mathrm{R} \& \mathrm{D}$ capital to create a firm-specific cost of capital. Most researchers simply include the cash flow to capital ratio in the model to proxy for the firm-specific cost of capital and test whether it enters in the presence of time dummies that are the same for all firms. This method assumes that all firms face the same R\&D price (cost of capital), except for the cash flow effect.

The third possibility is to stratify firms in some way that is related to the level of cash constraints that they face (for example, dividend-paying and non-dividend paying firms) estimate separate investment equations for each group, and test whether the coefficients are equal. This last was the method used by Fazzari, Hubbard, and Petersen (1988) in the paper that originated this literature. Note that these authors did not rely on the full Euler equation derivation, but used a version of the neoclassical accelerator model (the first model given above). See also Kaplan and Zingales (1997) for a critique of their approach, and Fazzari, Hubbard, and Petersen (2000) for a response to the critique.

During the past several years, various versions of the methodologies described above have been applied to data on the R\&D investment of U.S., U.K., French, German, Irish, and Japanese firms. The firms examined are typically the largest and most important manufactuing firms in their economy. For example, Hall (1992) found a large positive elasticity between R\&D and cash flow, using an accelerator-type model and a very large sample of U.S. manufacturing firms. The estimation methodology here controlled for both firm effects and simultaneity. Similarly and using some of the same data, Himmelberg and Petersen (1994) looked at a panel of 179 U.S. small firms in high-tech industries and find an economically large and statistically significant relationship between $R \& D$ investment and internal finance. 
More recently, J. Brown et al. (2009) have shown that both cash flow and the issuance of public equity are very important for younger U.S. firms during the 1990-2004 period, while they have little impact on mature firm R\&D investment. They focus on the high-technology sector (drugs, office and computing equipment, communications equipment, electronic components, scientific instruments, medical instruments, and software), which accounts for almost all of the increase in $\mathrm{R} \& \mathrm{D}$ during this period, and use Euler equation methods with fixed firm effects and industry-level year dummies to remove most of the variation due to unobserved differences in firm characteristics and demand shocks across industry. A novel finding in this paper and a companion paper by J. Brown and Petersen (2009) is the increased importance of public equity issuance in financing R\&D in the United States, which doubtless reflects a shift in expectations on the part of investors during this period.

Harhoff (1998) found weak but significant cash flow effects on R\&D for both small and large German firms, although Euler equation estimates for R\&D investment were uninformative due to the smoothness of $\mathrm{R} \& \mathrm{D}$ and the small sample size. Combining limited survey evidence with his regression results, he concludes that $\mathrm{R} \& \mathrm{D}$ investment in small German firms may be constrained by the availability of finance. Bond, Harhoff, and Van Reenen (1999) find significant differences between the cash flow impacts on R\&D and investment for large manufacturing firms in the United Kingdom and Germany. German firms in their sample are insensitive to cash flow shocks, whereas the investment of non-R\&D-doing UK firms does respond. Cash flow helps to predict whether a UK firm does $R \& D$, but not the level of that $R \& D$. They interpret their findings to mean that financial constraints are important for British firms, but that those which do R\&D are a self-selected group that face fewer constraints. This is consistent with the view that the desire of firms to smooth $\mathrm{R} \& \mathrm{D}$ over time combines with the relatively high cost of financing it to reduce $\mathrm{R} \& \mathrm{D}$ well below the level that would obtain in a frictionless world. 
Mulkay, Hall, and Mairesse (2001) perform a similar exercise using large French and U.S. manufacturing firms, finding that cash flow impacts are much larger in the U.S. than in France, both for $R \& D$ and for ordinary investment. Except for the well-known fact that R\&D exhibits higher serial correlation than investment (presumably because of higher adjustment costs), differences in behavior are between countries, not between investment types, suggesting that they are due to differences in the structure of financial markets rather than the type of investment, tangible or intangible. This result is consistent with evidence reported in Hall, Mairesse, Branstetter, and Crepon (1999) for the U.S., France, and Japan during an earlier time period, which basically finds that R\&D and investment on the one hand, and sales and cash flow on the other, are simultaneously determined in the United States (neither one "Granger-causes" the other, whereas in the other countries, there is little feedback from sales and cash flows to the two investments. Using a nonstructural R\&D investment equation together with data for the US, UK, Canada, Europe, and Japan, Bhagat and Welch (1995) found similar results for the 1985-1990 period, with stock returns predicting changes in R\&D more strongly for the US and UK firms.

Bougheas, Goerg, and Strobl (2001) examined the effects of liquidity constraints on R\&D investment using firm-level data for manufacturing firms in Ireland and also found evidence that $R \& D$ investment in these firms is financially constrained, in line with the previous studies of US and UK firms.

W. Brown (1997) argues that existing tests of the impact of capital market imperfections on innovative firms cannot distinguish between two possibilities: 1) capital markets are perfect and different factors drive the firm's different types of expenditure or 2) capital markets are imperfect and different types of expenditure react differently to a common factor (shocks to the supply of internal finance). He then compares the sensitivity of investment to cash flow for innovative and 
non-innovative firms in the UK. The results support the hypothesis that capital markets are imperfect, finding that the investment of innovative firms is more sensitive to cash flow.

The conclusions from this body of empirical work are several: first, there is solid evidence that debt is a disfavored source of finance for R\&D investment; second, the "Anglo-Saxon" economies, with their thick and highly developed stock markets and relatively transparent ownership structures, typically exhibit more sensitivity and responsiveness of R\&D to cash flow than continental economies; third, and much more speculatively, this greater responsiveness may arise because they are financially constrained, in the sense that they view external sources of finance as much more costly than internal, and therefore require a considerably higher rate of return to investments done on the margin when they are tapping these sources. However, it is perhaps equally likely that this responsiveness occurs because firms are more sensitive to demand signals in thick financial equity markets; a definitive explanation of the "excess sensitivity" result awaits further research. ${ }^{9}$ In addition to these results, the evidence from Germany and some other countries suggests that small firms are more likely to face this difficulty than large established firms (not surpisingly, if the source of the problem is a "lemons" premium).

From a policy perspective, these results point to another reason why it may be socially beneficial to offer tax incentives to companies, especially to small and new firms, in order to reduce the cost of capital they face for R\&D investment. Many governments, including not only those in the developed world (e.g., the United States and the United Kingdom), but also in the developing world (e. g., Chile, Brazil, and Argentina) currently have such programs. Such a policy approach simply observes that the cost of capital is relatively high for R\&D and tries to close the gap via a tax

\footnotetext{
${ }^{9}$ It is also true that much of the literature here has tended to downplay the role of measurement error in drawing conclusions from the results. Measurement error in Tobin's q, cash flow, or output is likely to be sizable and will ensure that all variables will enter any specification of the R\&D investment equation significantly, regardless of whether they truly belong or not. Instrumental variables estimation is a partial solution, but only if all the errors are serially uncorrelated, which is unlikely.
} 
subsidy. However, there is an alternative approach relying on the private sector that attempts to close the financing gap by reducing the degree of asymmetric information and moral hazard rather than simply subsidizing the investment. We turn to this topic in the next section.

\section{Small Firms, Startup Finance, and Venture Capital}

As should be apparent from much of the preceding discussion, any problems associated with financing investments in new technology will be most apparent for new entrants and startup firms. For this reason, many governments already provide some of form of assistance for such firms, and in many countries, especially the United States but also others such as Israel and Canada, there exists a private sector "venture capital" industry that is focused on solving the problem of financing innovation for new and young firms. This section of the paper reviews what we know about these alternative funding mechanisms, beginning with then discussing the venture capital solution and then discussing public policy efforts. The discussion focuses on the United States for the most part, since the sector there is often the model for other countries, and most of the empirical evidence is based on US data.

Venture capital can be defined as independently managed, dedicated capital focusing on equity or equity-linked investments in privately held, high-growth companies. Typically, these funds are raised from institutional and wealthy individual investors, through partnerships with a decadelong duration. These funds are invested in young firms, typically in exchange for preferred stock with various special privileges. Ultimately, the venture capitalists sell these firms to corporate acquirers or else liquidate their holdings after taking the firms public.

The first venture firm, American Research and Development, was formed in 1946 and invested in companies commercializing technology developed during the Second World War. 
Because institutions were reluctant to invest, it was structured as a publicly traded closed-end fund and marketed mostly to individuals, a structure emulated by its successors.

By 1978 limited partnerships had become the dominant investment structure. Limited partnerships have an important advantage in the United States: capital gains taxes are not paid by the limited partnership. Instead, only the taxable investors in the fund pay taxes. Venture partnerships have predetermined, finite lifetimes. To maintain limited liability, investors must not become involved in the management of the fund.

Activity in the venture industry increased dramatically in early 1980s. Much of the growth stemmed from the US Department of Labor's clarification of Employee Retirement Income Security Act's 'prudent man' rule in 1979, which had prohibited pension funds from investing substantial amounts of money into venture capital or high-risk asset classes. The rule clarification explicitly allowed pension managers to invest in high-risk assets, including venture capital.

The subsequent years saw both very good and trying times for venture capitalists. Venture capitalists backed many successful companies, including Apple Computer, Cisco, Genentech, Google, Netscape, Starbucks, and Yahoo! But commitments to the venture capital industry were very uneven, creating a great deal of instability. The annual flow of money into venture funds increased by a factor of ten during the early 1980s. From 1987 through 1991, however, fund-raising steadily declined as returns fell. Between 1996 and 2003, this pattern was repeated. Later in this chapter we discuss the reasons behind this cyclicality.

Venture capital investing can be viewed as a cycle. In this section, we follow the cycle of venture capital activity. We begin with the formation of venture funds. We then consider the process by which such capital is invested in portfolio firms, and the exiting of such investments. We end with a discussion of open research questions, including those relating to internationalization and the real effects of venture activity. 


\subsection{Venture Investing}

The heart of the venture capital process is the connection between venture capitalists and the firms in which they invest. As discussed earlier, the economic and management literature emphasizes the informational asymmetries that characterize young firms, particularly in hightechnology industries. These problems make it difficult for investors to assess firms, and permit opportunistic behavior by entrepreneurs after finance is received. Specialized financial intermediaries, such as venture capitalists, address these problems by intensively scrutinizing firms before providing capital and monitoring them afterwards.

Economic theory examines the role that venture capitalists play in mitigating agency conflicts between entrepreneurs and investors. The improvement in efficiency might be due to the active monitoring and advice that is provided (Cornelli and Yosha, 2003; Hellmann, 1998; Marx, 1994), the screening mechanisms employed (Chan, 1983), the incentives to exit (Berglöf, 1994), the proper syndication of the investment (Admati and Pfleiderer, 1994), or investment staging (Bergmann-Hege, 1998; Sahlman, 1990).

Staged capital infusion is the most potent control mechanism a venture capitalist can employ. The shorter the duration of an individual round of financing, the more frequently the venture capitalist monitors the entrepreneur's progress. The duration of funding should decline and the frequency of re-evaluation increase when the venture capitalist believes that conflicts with the entrepreneur are likely.

If monitoring and information gathering are important - as models such as those of Amit, Glosten and Muller (1990) and Chan (1983) suggest - venture capitalists should invest in firms where asymmetric problems are likely, such as early-stage and high-technology firms with intangible assets. The capital constraints faced by these companies will be large and these investors will address them. 
Gompers (1995) shows that venture capitalists concentrate investments in early-stage companies and high-technology industries where informational asymmetries are significant and monitoring is valuable. He finds that early-stage firms receive significantly less money per round. Increases in asset tangibility are associated with longer financing duration and reduce monitoring intensity, presumably because such assets increase the salvage value of the firm if the enterprise fails.

In a related paper, Kaplan and Strömberg (2003) document how venture capitalists allocate control and ownership rights contingent on financial and non-financial performance. If a portfolio company performs poorly, venture capitalists obtain full control. As performance improves, the entrepreneur obtains more control. If the firm does well, the venture capitalists relinquish most of their control rights but retain their equity stake.

Related evidence comes from Hsu (2004), who studies the price entrepreneurs pay to be associated with reputable venture capitalists. He analyses firms which received financing offers from multiple venture capitalists. Hsu shows that high investor experience is associated with a substantial discount in firm valuation.

Venture capitalists usually make investments with peers. The lead venture firm involves other venture firms. One critical rationale for syndication in the venture industry is that peers provide a second opinion on the investment opportunity and limit the danger of funding bad deals.

Lerner (1994a) finds that in the early investment rounds experienced venture capitalists tend to syndicate only with venture firms that have similar experience. He argues that, if a venture capitalist were looking for a second opinion, then he would want to get one from someone of similar or greater ability, certainly not from someone of lesser ability.

The advice and support provided by venture capitalists is often embodied in their role on the firm's board of directors. Lerner (1995) examines whether venture capitalists' representation on the boards of the private firms in their portfolios is greater when the need for oversight is larger, looking 
at changes in board membership around the replacement of CEOs. He finds that an average of 1.75 venture capitalists are added to the board between financing rounds when a firm's CEO is replaced in the interval; between other rounds 0.24 venture directors are added. No differences are found in the addition of other outside directors.

Hochberg (2005) studies the influence of venture capitalists on the governance of a firm following its initial public offering (IPO). Venture-backed firms manage earnings less in the IPO year, as measured by discretionary accounting accruals. Venture-backed firms also experience a stronger wealth effect when they adopt a poison pill, which implies that investors are less worried that the poison pill will entrench management at the expense of shareholders. Finally, venturebacked firms more frequently have independent boards and audit and compensation committees, as well as separate CEOs and chairmen.

So far, this section has highlighted the ways in which venture capitalists can successfully address agency problems in portfolio firms. During periods when the amount of money flowing into the industry grows dramatically, however, competition between venture groups can introduce distortions. This is shown in Figure 3, which shows relationship between venture returns and the amount invested in these funds. The returns are measured by the Sand Hill Index, which is a valueweighted and continuously-invested index of the value of venture funded companies from their first round of institutional funding to their exit. ${ }^{10}$ The money invested series (also from Sand Hill Econometrics) is the total dollars invested in the companies in the Sand Hill Index each month.

Gompers and Lerner (2000) examine the relation between the valuation of venture deals and inflows into venture funds. Doubling inflows leads to a 7-21 per cent increase in valuation levels. But success rates do not differ significantly between investments made during periods of low inflows and valuations on the one hand and those made in booms on the other. The results indicate that the

\footnotetext{
${ }^{10}$ See the Sand Hill Econometrics website for details on the construction of this indes. http://www.sandhillecon.com
} 
price increases reflect increasing competition for investment, rather than changes in the expected returns.

\subsection{Exiting}

A third major area of research has been the process whereby venture funds exit investments. This topic is important because, in order to make money on their investments, venture capitalists must sell their equity stakes.

Initial research into the exiting of venture investments focused on Initial Public Offerings (IPOs), reflecting the fact that the most profitable exit opportunity is usually an IPO. Barry et al. (1990) and Megginson and Weiss (1991) document that venture capitalists hold significant equity stakes and board positions in the firms they take public, which they continue to hold a year after the IPO. They argue that this pattern reflects the certification they provide to investors that the firms they bring to market are not overvalued. Moreover, they show that venture-backed IPOs have less of a positive return on their first trading day, a finding that has been subsequently challenged (Lee and Wahal, 2004; Kraus, 2002). The authors suggest that investors need a smaller discount because the venture capitalist has certified the offering's quality.

Subsequent research has examined the timing of the exit decision. Several potential factors affect when venture capitalists choose to bring firms public. Lerner (1994b) examines how the valuation of public securities affects whether and when venture capitalists choose to finance companies in another private round in preference to taking the firm public. He shows that investors tend to take the firm public when the market value is high, relying on private financings when valuations are lower. Seasoned venture capitalists appear more proficient at timing IPOs. This finding is consistent with the work by J. Brown, Fazzari, and Petersen on the importance of public equity financing of R\&D during the 1990s stock market boom. 
Another consideration may be the venture capitalist's reputation. Gompers (1996) argues that young venture firms have incentives to 'grandstand', or take actions that signal their ability to potential investors. Specifically, young venture firms bring companies public earlier than older one to establish a reputation and successfully raise new funds. Gompers shows that the effect of recent IPOs on the amount of capital raised is stronger for young venture firms, providing them with greater incentives to bring companies public earlier.

Lee and Wahal (2004) propose a variant of the 'grandstanding' hypothesis: they posit that venture firms have an incentive to underprice IPOs. The publicity surrounding a successful offering will enable the venture group to raise more capital than it could otherwise. Lee and Wahal confirm this hypothesis by showing a positive relationship between first-day returns and subsequent fundraising by venture firms.

The typical venture firm, however, does not sell its equity at the time of the IPO. After some time, venture capitalists usually return money to their limited partners by transferring the shares to their investors, who are free either to hold or sell them. Gompers and Lerner (1998a) examine these distributions. After significant increases in stock prices prior to distribution, abnormal returns around the time of the distribution are negative. Cumulative excess returns for the 12 months following the distribution also appear to be negative. While the overall level of venture capital returns does not exhibit abnormal returns relative to the market (Brav and Gompers, 1997), there is a distinct rise and fall around the time of the stock distribution. The results are consistent with venture capitalists possessing inside information and with the (partial) adjustment of the market to that information.

A related research area is venture-fund performance. Kaplan and Schoar (2005) show substantial performance persistence across consecutive venture funds with the same general partners. General partners that outperform the industry in one fund are likely to outperform in the 
next fund, while those who underperform in one fund are likely to underperform with the next fund. These results contrast with those of mutual funds, where persistence is difficult to identify.

Cochrane (2005) estimates the returns of venture capital investments. He notes that many analyses of returns focus only on investments that go public, get acquired, or go out of business. Such calculations may produce biased returns by concentrating only on the portfolio's 'winners' and outright failures, ignoring those firms that remain within the fund for longer periods. Cochrane develops a maximum likelihood estimate that uses existing data, but adjusts for these selection biases. While these papers - as well as Gompers and Lerner (1997) and Jones and Rhodes-Kropf (2003) - represent a first step towards understanding these issues, much more work remains to be done in this area.

\subsection{Venture Fund-raising}

Finally, research into the formation of venture funds has focused on two topics. First, the commitments to the venture capital industry have been highly variable since the mid-1970s. Understanding the determinants of this variability has been a topic of continuing interest to researchers. Second, the structure of venture partnerships has attracted increasing attention.

First, Poterba $(1987 ; 1989)$ notes that the fluctuations could arise from changes in either the supply of or the demand for venture capital. It is very likely, he argues, that decreases in capital gains tax rates increase commitments to venture funds, even though the bulk of the funds are from taxexempt investors. The drop in the tax rate may spur corporate employees to become entrepreneurs, thereby increasing the need for venture capital. The increase in demand due to greater entrepreneurial activity leads to more venture fund-raising.

Gompers and Lerner (1998b) find empirical support for Poterba's claim: lower capital gains taxes have particularly strong effects on venture capital supplied by tax-exempt investors. This 
suggests that the primary mechanism by which capital gains tax cuts affect venture fund-raising is the higher demand of entrepreneurs for capital. The authors also find that a number of other factors influence venture fund-raising, such as regulatory changes and the returns of venture funds.

A second line of research has examined the contracts that govern the relationship between investors (limited partners) and the venture capitalist (general partner). Gompers and Lerner (1999) find that compensation for older and larger venture capital organizations is more sensitive to performance than that of other venture groups. Also, the cross-sectional variation in compensation terms for younger, smaller venture organizations is considerably lower. The fixed component of compensation is higher for smaller, younger funds and funds focusing on high-technology or earlystage investments. Finally, Gompers and Lerner do not find any relationship between the incentive compensation and performance.

The authors argue that these results are consistent with a learning model in which neither the venture capitalist nor the investor knows the venture capitalist's ability. With his early funds, the venture capitalist will work hard even without explicit pay-for-performance incentives: if he can establish a good reputation, he can raise subsequent funds. These reputation concerns lead to lower pay for performance for smaller and younger venture organizations. Once a reputation has been established, explicit incentive compensation is needed to induce the proper effort.

Covenants also play an important role in limiting conflicts in venture partnerships. Their use may be explained by two hypotheses. First, because negotiating and monitoring covenants are costly, they will be employed when monitoring is easier and the potential for opportunistic behaviour is greater. Second, in the short run the supply of venture capital services may be fixed, with a modest number of funds of carefully limited size raised each year. Increases in demand may lead to higher prices when contracts are written. Higher prices may include not only increases in monetary compensation, but also greater consumption of private benefits through fewer covenants. 
Gompers and Lerner (1996) show that both supply and demand conditions and costly contracting are important in determining contractual provisions. Fewer restrictions are found in funds established during years with greater capital inflows and funds, when general partners enjoy higher compensation. The evidence illustrates the importance of general market conditions on the restrictiveness of venture partnerships. In periods when venture capitalists have relatively more bargaining power-for instance, when there is a big increase in the funds being invested in venture funds - the venture capitalists are able to raise money with fewer strings attached.

\subsection{The globalization of venture capital}

While financial economists know much more about venture capital than they did a decade ago, there are many unresolved issues. We highlight here three promising areas, beginning with the globalization of the industry.

The rapid growth in the U.S. venture capital market has led institutional investors to look increasingly at private equity alternatives abroad. To date, however, outside of the United Kingdom (where performance of funds has been quite poor), Israel, Canada and New Zealand, there has been little venture capital activity abroad. Figure 4 shows venture capital as a share of GDP in 2007 for a number of countries. ${ }^{11}$ Black and Gilson (1998) argue that the key source of the U.S. competitive advantage in venture capital is the existence of a robust IPO market. Venture capitalists can commit to transfer control back to the entrepreneur when a public equity market for new issues exists. This commitment device is unavailable in economies dominated by banks, such as Germany and Japan.

The rapid growth in the US venture capital market has led institutional investors to look abroad. In a pioneering study, Jeng and Wells (2000) examine the factors that influence venture

\footnotetext{
${ }^{11}$ One potential source of confusion is that the term venture capital is used differently different in Europe and Asia. Abroad, venture capital often refers to all private equity, including buyout, late stage, and mezzanine financing (which represent the vast majority of the private equity pool in most overseas markets). In the U.S., these are separate classes. The data in Figures 3 and 4 are corrected for this fact and we confine our discussion of international trends to venture capital using the restrictive, U.S. definition.
} 
fund-raising internationally. They find that the strength of the IPO market is an important determinant of venture commitments, supporting Black and Gilson's hypothesis that the key to a successful venture industry is the existence of robust IPO markets. Jeng and Wells find, however, that the IPO market does not influence commitments to early-stage funds as much as those to laterstage ones. Much more remains to be explored regarding the internationalization of venture capital. Certainly, with a few exceptions such as Australia, China, India, and Japan, venture capital remains focused on the United States, as Figure 5 illustrates. Relative to the size of their GDP share, the European Union countries have almost no seed and startup funding when compared to the rest of the developed world.

A related question is why other financial intermediaries (such as banks) cannot duplicate these features of the venture capitalists, and undertake the same sort of monitoring. Economists have suggested several explanations for the apparent superiority of venture funds in this regard. First, because regulations limit banks' ability to hold shares, at least in the U.S., they cannot freely use equity. Second, banks may not have the necessary skills to evaluate projects with few collateralizable assets and significant uncertainty. Finally, venture funds' high-powered compensation schemes give venture capitalists incentives to monitor firms closely. Banks sponsoring venture funds without high-powered incentives have found it difficult to retain personnel.

\subsection{The real effects of venture capital}

A second area is even thornier: the impact of venture capital on the economy. While theorists have suggested a variety of mechanisms by which venture capital may affect innovation, the empirical record is more mixed. It might be thought that establishing a relationship between venture capital and innovation would be straightforward. For instance, one could look in regressions across industries and time whether, controlling for R\&D spending, venture capital funding has an impact 
on various measures of innovation. But even a simple model of the relationship between venture capital, $\mathrm{R} \& \mathrm{D}$, and innovation suggests that this approach is likely to give misleading estimates.

Both venture funding and innovation could be positively related to a third unobserved factor, the arrival of technological opportunities. Thus, there could be more innovation at times that there was more venture capital, not because the venture capital caused the innovation, but rather because the venture capitalists reacted to some fundamental technological shock which was sure to lead to more innovation. To date, only a handful of papers have attempted to address these challenging issues.

The first of these papers, Hellmann and Puri (2000), examines a sample of 170 recently formed firms in Silicon Valley, including both venture-backed and non-venture firms. Using questionnaire responses, they find empirical evidence that venture capital financing is related to product market strategies and outcomes of startups. They find that firms that are pursuing what they term an innovator strategy (a classification based on the content analysis of survey responses) are significantly more likely to obtain venture capital and also obtain it more quickly. The presence of a venture capitalist is also associated with a significant reduction in the time taken to bring a product to market, especially for innovators. Furthermore, firms are more likely to list obtaining venture capital as a significant milestone in the lifecycle of the company as compared to other financing events.

The results suggest significant interrelations between investor type and product market dimensions, and a role of venture capital in encouraging innovative companies. Given the small size of the sample and the limited data, they can only modestly address concerns about causality. Unfortunately, the possibility remains that more innovative firms select venture capital for financing, rather than venture capital causing firms to be more innovative. 
Kortum and Lerner (2000), by way of contrast, examine whether these patterns can be discerned on an aggregate industry level, rather than on the firm level. They address concerns about causality in two ways. First, they exploit the major discontinuity in the recent history of the venture capital industry: as discussed above, in the late 1970s, the U.S. Department of Labor clarified the Employee Retirement Income Security Act, a policy shift that freed pensions to invest in venture capital. This shift led to a sharp increase in the funds committed to venture capital. This type of exogenous change should identify the role of venture capital, because it is unlikely to be related to the arrival of entrepreneurial opportunities. They exploit this shift in instrumental variable regressions. Second, they use $\mathrm{R} \& \mathrm{D}$ expenditures to control for the arrival of technological opportunities that are anticipated by economic actors at the time, but that are unobserved to econometricians. In the framework of a simple model, they show that the causality problem disappears if they estimate the impact of venture capital on the patent-R\&D ratio, rather than on patenting itself.

Even after addressing these causality concerns, the results suggest that venture funding does have a strong positive impact on innovation. The estimated coefficients vary according to the techniques employed, but on average a dollar of venture capital appears to be three to four times more potent in stimulating patenting than a dollar of traditional corporate R\&D. The estimates therefore suggest that venture capital, even though it averaged less than three percent of corporate R\&D from 1983 to 1992, is responsible for a much greater share-perhaps ten percent—of U.S. industrial innovations in this decade. These findings have been supported by recent working paper by Mollica and Zingales (2007), who also use an instrumental variable approach based on state pension fund resources to look at the relationship of venture capital and innovation and find a strong relationship. 
Some of the most interesting theoretical work in recent years has focused not on the question of whether venture capitalists spur innovation, but rather on the societal consequences of the relationship between venture-backed entrepreneurship and innovation. Landier (2006) presents a model in which entrepreneurial venture succeed or fail on the basis of ability and luck. ${ }^{12}$ He argues that as the venture progresses, the entrepreneur is likely to learn about the likely eventual success of the venture, but that the decision to continue or abandon the venture will not be the same in all environments. In particular, the decision depends critically on how expensive it would be to raise capital for a new venture from investors after a failure. In this setting, Landier shows, multiple equilibria can arise. If the cost of capital for a new venture after a failure is not very high, entrepreneurs will be willing to readily abandon ventures, and failure is commonplace but not very costly. Alternatively, if the cost of capital for failed entrepreneurs is high, only extremely poor projects will be abandoned. Thus, societies may differ dramatically in the prevalence of experimentation in high-risk, innovative ventures. But certainly, given the fact that even the question of whether venture capitalists make private returns which compensate them for the risk that they take on is controversial (Kaplan and Schoar, 2005), it is premature to conclude what the social returns are.

\subsection{Government funding for startup firms}

One provocative finding from Jeng and Wells's analysis is that government policy can dramatically affect the health of the venture sector. Researchers have only begun to examine the ways in which policymakers can catalyse the growth of venture capital and the companies in which they invest (Irwin and Klenow, 1996; Lerner, 1999; Wallsten, 2000; Avnimelech and Teubal, 2004; Gilson, 2008). Clearly, much more needs to be done in this arena.

\footnotetext{
${ }^{12}$ See also Gromb and Scharfstein (2002) for a thoughtful theoretical analysis that touches on many of these issues.
} 
Examples of such programs are the U.S. Small Business Investment Company (SBIC) and Small Business Innovation Research (SBIR) programs. Together, these programs disbursed $\$ 2.4$ billion in 1995, more than $60 \%$ of the amount from venture capital in that year (Lerner 1998a). In Germany, more than 800 federal and state government financing programs have been established for new firms in the recent past (OECD 1995). In 1980, the Swedish established the first of a series of investment companies (along with instituting a series of measures such as reduced capital gains taxes to encourage private investments in startups), partly on the United States model. By 1987, the government share of venture capital funding was 43 percent (Karaomerliolu and Jacobsson 1999). Recently, the UK has instituted a series of government programs under the Enterprise Fund umbrella which allocate funds to small and medium-sized firms in high technology and certain regions, as well as guaranteeing some loans to small businesses (Bank of England 2001). There are also programs at the European level.

A limited amount of evidence, most of it U.S.-based, exists as to the effectiveness and "additionality" of these programs (see Lerner (2009) for a review of the key programs and their evaluaitons). In most cases, evaluating the success of the programs is difficult due to the lack of a "control" group of similar firms that do not receive funding. ${ }^{13}$ Therefore most of the available studies are based on retrospective survey data provided by the recipients; few attempt to address the question of performance under the counterfactual seriously. A notable exception is the study by Lerner (1999), who looks at 1435 SBIR awardees and a matched sample of firms that did not receive awards, over a ten-year post-award period. Because most of the firms are privately held, he is unable to analyze the resulting valuation or profitability of the firms, but he does find that firms receiving SBIR grants grow significantly faster than the others after receipt of the grant. He attributes some of

\footnotetext{
13 See Jaffe (2002) for a review of methodologies for evaluation such government programs. For a complete review of
} the SBIR program, including some case studies, see the National Research Council (1998). 
this effect to "quality certification" by the government that enables the firm to raise funds from private sources as well. ${ }^{14}$

A series of papers by Czarnitzki and co-authors (Aerts and Czarnitzki, 2003; Almus and Czarnitzki, 2004; Czarnitzki and Hussinger, 2006) have looked at the performance of firms that receive public R\&D subsidies in several European countries such as Belgium and Germany, using treatment effect analysis. They generally find that such subsidies do not completely displace private expenditure on $\mathrm{R} \& \mathrm{D}$ (that is, they are additional) and that they are productive in the sense that they result in patenting by the firm. Hall and Maffioli (2008) survey a similar set of results for large Latin American economies and reach a more nuanced conclusion.

\section{Conclusions}

Based on the literature surveyed here, what do we know about the costs of financing $R \& D$ investments and the possibility that some kind of market failure exists in this area? Several main points emerge:

First, there is fairly clear evidence, based on theory, surveys, and empirical estimation, that small and startup firms in R\&D-intensive industries face a higher cost of capital than their larger competitors and than firms in other industries. In addition to compelling theoretical arguments and empirical evidence, the mere existence of the $\mathrm{VC}$ industry and the fact that it is concentrated precisely where these startups are most active suggests that this is so. The fact that ex post venture returns may lag the market, however, remains a puzzle and makes a clear-cut conclusion more complex.

14 Also see Spivack (2001) for further studies of such programs, including European studies, and David, Hall, and Toole (2000) and Klette, Moen, and Griliches Klette (2000) for surveys of the evaluation of government R\&D programs in general. 
Second, the evidence for a financing gap for large and established R\&D firms is harder to establish. It is certainly the case that these firms prefer to use internally generated funds for financing investment, but less clear that there is an argument for intervention, beyond the favorable tax treatment that currently exists in many countries. ${ }^{15}$

Third, the VC solution to the problem of financing innovation has its limits: First, it does tend to focus only on a few sectors at a time, and to make investment with a minimum size that is too large for startups in some fields. Second, good performance of the VC sector requires a thick market in small and new firm stocks (such as NASDAQ) in order to provide an exit strategy for early stage investors. Introducing a VC sector into an economy where it is not already present is nontrivial as it requires the presence of at least three interacting institutions: investors, experienced venture fund managers, and a market for IPOs.

Fourth, the effectiveness of government incubators, seed funding, loan guarantees, and other such policies for funding $R \& D$ deserves further study, ideally in an experimental or quasiexperimental setting. In particular, studying the cross-country variation in the performance of such programs would be desirable, because the outcomes may depend to a great extent on institutional factors that are difficult to control for using data from within a single country.

Based on the survey of the literature presented here, other areas of interest for future research appear to be worthwhile. A longstanding debate in the literature is over the interaction between corporate governance and corporate finance and its impact on long term investment, including investment in intangibles such as $\mathrm{R} \& \mathrm{D}$. Although in principle one might have thought that financial markets focused on quarterly performance, such as those in the Anglo-Saxon economies,

\footnotetext{
15 It is important to remind the reader of the premise of this paper: we are focusing only on the financing gap arguments for favorable treatment of R\&D and ignoring (for the present) the arguments based on R\&D spillovers and externalities. There is good reason to believe that the latter is a much more important consideration for large established firms, especially if we wish those firms to undertake basic research that is close to industry but with unknown applications (the Bell Labs model).
} 
would discourage such investment, this appears not to be the case, at least in the United States. However, for several large European countries, we have limited evidence that the required rate of return to R\&D investment is perhaps somewhat lower than in the U.S. and the U.K., especially when the firm has a large majority shareholder (see the Hall, Mairesse, and Mohnen chapter, this volume). This fact suggests that for these firms at least, the stability provided by concentrated ownership may encourage $\mathrm{R} \& \mathrm{D}$. At the same time, the more fluid financial markets with active markets for corporate control seem to be better at financing new entrants, startups, and more overall investment in innovation. The future challenge is to understand more completely the interaction of financial market discipline with various forms of corporate governance and how this influences the organization and performance of innovation. 


\section{References}

Admati, A., Pfleiderer, P. (1994). "Robust financial contracting and the role for venture capitalists." Journal of Finance 49, 371-402.

Aerts, K. and D. Czarnitzki (2006). "The Impact of Public R\&D-Funding in Flanders.” Brussels, Belgium: IWT Study No. 54.

Aghion, P., Howitt, P. (1997). Endogenous Growth Theory. The MIT Press, Cambridge.

Akerlof, G.A. (1970). “The Market for 'Lemons': Quality, Uncertainty, and the Market Mechanism.” Quarterly Journal of Economics 84, 488-500.

Alam, P., Walton, K.S. (1995). "Information Asymmetry and Valuation Effects of Debt Financing." Financial Review 30(2), 289-311.

Alderson, M.J., Betker, B.L. (1996). "Liquidation Costs and Accounting Data." Financial Management 25(2), 25-36.

Almus, M. and D. Czarnitzki (2003). “The Effects of Public R\&D Subsidies on Firms' Innovation Activities: The Case of East Germany." Journal of Business and Economic Statistics 21(2): 226236.

Amit, R., Glosten, L., Muller, E. (1990). "Entrepreneurial ability, venture investments, and risk sharing." Management Science 36, 1232-45.

Anton, J.J., Yao, D.A. (1998). "The Sale of Intellectual Property: Strategic Disclosure, Property Rights, and Incomplete Contracts." Working paper, The Wharton School, University of Pennsylvania.

Arellano, M., Bond, S. (1991). "Some Tests of Specification for Panel Data: Monte Carlo Evidence and an Application to Employment Equations.” Review of Economic Studies 58, 277-297.

Arrow, K.J. (1962). “Economic Welfare and the Allocation of Resources for Invention.” In: Nelson, R. (Ed.), The Rate and Direction of Inventive Activity. Princeton, NJ. 
Auerbach, A.J. (1984). “Taxes, Firm Financial Policy, and The Cost of Capital: An Empirical Analysis." Journal of Public Economics 23, 27-57.

Avnimelech, G. and M. Teubal (2004). "Emergence and Development of Venture Capital in Israel and the Role of Policy: a Macro / Microeconomic Perspective.” In: Bartzokas, A. and S. Mani (eds.), Financial Systems, Corporate Investment in Innovation and Venture Capital. London: Edward Elgar.

Bank of England. (2001). Finance for Small Firms - An Eighth Report. Domestic Finance Division, Bank of England, London.

Barry, C., Muscarella, C., Peavy III, J., Vetsuypens, M. (1990). "The role of venture capital in the creation of public companies: evidence from the going public process." Journal of Financial Economics 27, 447-71.

Bergemann, D., Hege, U. (1998). "Venture capital financing, moral hazard, and learning." Journal of Banking and Finance 22, 703-735.

Berglöf, E. (1994). "A control theory of venture capital finance." Journal of Law, Economics, and Organizations 10, 247-67.

Bhagat, S., Welch, I. (1995). "Corporate Research and Development Investments: International Comparisons." Journal of Accounting and Economics 19, March-May.

Bhattacharya, S., Ritter, J.R. (1983). "Innovation and Communication: Signaling with Partial Disclosure." Review of Economic Studies L, 331-46.

Black, B., Gilson, R. (1998). "Venture capital and the structure of capital markets: banks versus stock markets." Journal of Financial Economics 47, 243-77.

Blair, M.M., Litan, R.E. (1990). Corporate Leverage and Leveraged Buyouts in the Eighties. Brookings Institution, Washington, DC. 
Blass, A.A., Yosha, O. (2001). "Financing R\&D in Mature Companies: An Empirical Analysis." Working Paper, Bank of Israel, Tel Aviv University, and CEPR.

Bond, S., Harhoff, D., Van Reenen, J. (1999). "Investment, R\&D, and Financial Constraints in Britain and Germany.” Institute of Fiscal Studies Working Paper No. 99/5, London.

Bougheas, S., Goerg, H., Strobl, E. (2001). "Is R\&D Financially Constrained? Theory and Evidence from Irish Manufacturing.” University of Nottingham, Nottingham.

Brav, A., Gompers, P. (1997). "Myth or reality? Long-run underperformance of initial public offerings; evidence from venture capital and nonventure capital-backed IPOs." Journal of Finance 52, 1791-821.

Brown, J. R. and B. C. Petersen (2009). "Why has the investment-cash flow Sensitivity declined so sharply? Rising R\&D and equity market developments.” Journal of Banking and Finance 33: 971-984.

Brown, J. R. and B. C. Petersen (2009). "Cash holdings and R\&D smoothing." University of Montana and Washington University in St. Louis: manuscript.

Brown, J. R., S. M. Fazzari, and B. C. Petersen (2009). "Financing innovation and growth: Cash flow, external equity, and the 1990s R\&D boom.” Journal of Finance LXIV(1): 151-185.

Brown, W. (1997). "R\&D Intensity and Finance: Are Innovative Firms Financially Constrained?." London School of Economics Financial Market Group, London.

Campbell, J. Y., A.W. Lo, and A. C. MacKinlay (1997). The Econometrics of Financial Markets. Princeton, NJ: Princeton University Press.

Chan, Y. (1983). "On the positive role of financial intermediation in allocation of venture capital in a market with imperfect information.” Journal of Finance 38, 1543-68.

Cho, S. (1992). "Agency Costs, Management Stockholding, and Research and Development Expenditures." Seoul Journal of Economics 5(2), 127-52. 
Cochrane, J. (2005). “The risk and return of venture capital." Journal of Financial Economics 75, 3-52.

Cornelli, F., Yosha, O. (2003). "Stage financing and the role of convertible debt." Review of Economic Studies $70,1-32$.

Czarnitzki, D. and K. Hussinger (2004). "he Link Between R\&D Subsidies, R\&D Spending, and Technological Performance.” Mannheim, Germany: ZEW Discussion Paper No. 04-56.

Chung, K.H., Wright, P. (1998). "Corporate Policy and Market Value: A q Theory Approach.” Review of Quantitative Finance and Accounting 11(3), 293-310.

Eng, L. L., Shackell, M. (2001). "The Implications of Long Term Performance Plans and Institutional Ownership for Firms' Research and Development Investments." Journal of Accounting, Auditing and Finance 16(2), 117-39.

Fazzari, S.M., Hubbard, R.G., Petersen, B.C. (1988). "Financing Constraints and Corporate Investment." Brookings Papers on Economic Activity 1988(1), 141-205. . (2000). "Investment-Cash Flow Sensitivities Are Useful: A Comment on Kaplan and Zingales." Quarterly Journal of Economics 115, 695-705.

Francis, J., Smith, A. (1995). “Agency Costs and Innovation: Some Empirical Evidence," Journal of Accounting and Economics 19(2/3), 383-409.

Gilson, R. J. (2003). "Engineering a Venture Capital Market: Lessons from the American Experience." Stanford Law Review 55: 1067.

Griliches, Z. (1992). “The Search for R\&D Spillovers.” Scandinavian Journal of Economics 94, S29-S47.

Gompers, P. (1996). "Grandstanding in the venture capital industry." Journal of Financial Economics 42, 133-56. . (1995). “Optimal investment, monitoring, and the staging of venture capital." Journal of Finance 50, 1461-89. 
, Lerner, J. (2000). "Money chasing deals? The impact of fund inflows on private equity valuations." Journal of Financial Economics 55, 281-325.

. (1999). "An analysis of compensation in the U.S. venture capital partnership." Journal of Financial Economics 51, 3-44. . (1998b). "What drives venture fundraising?." Brookings Papers on Economic Activity-Microeconomics, 149-92. . (1998a). "Venture capital distributions: short- and long-run reactions." Journal of Finance 53, 2161-83. . (1997). "Risk and reward in private equity investments: the challenge of performance assessment." Journal of Private Equity 1, 5-12. (1996). "The use of covenants: an empirical analysis of venture partnership agreements." Journal of Law and Economics 39, 463-98.

Hajivassiliou, V., and F. Savignac (2008). "Financial constraints and a firm's decision and ability of innovate: Establishing direct and reverse effects." London School of Economics and Banque de France: manuscript.

Hall, B. H. (1996). "The Private and Social Returns to Research and Development." In: Smith, B.L.R, Barfield, C.E. (Eds.), Technology, R\&D, and the Economy, 140-83. Brookings Institution and the American Enterprise Institute, Washington, DC.

. (1994). "Corporate Capital Structure and Investment Horizons in the United States, 1976-1987." Business History Review 68, 110-143.

. (1993). "R\&D Tax Policy During the Eighties: Success or Failure?." Tax Policy and the Economy 7, 1-36. . (1992). "Research and Development at the Firm Level: Does the Source of Financing Matter?.” NBER Working Paper No. 4096, June. 
(1990). "The Impact of Corporate Restructuring on Industrial Research and

Development.” Brookings Papers on Economic Activity 1990(1), 85-136.

, Maffioli, A. (2008), "Evaluating the Impact of Technology Development Funds in

Emerging Economies: Evidence from Latin America," European Journal of Development Research 20 (2): 172-198, 2008.

, Mairesse, J., Branstetter, L., Crepon, B. (1999). "Does Cash Flow Cause Investment and R\&D: An Exploration using Panel Data for French, Japanese, and United States Firms in the Scientific Sector.” In: Audretsch, D., Thurik, A.R. (Eds.), Innovation, Industry Evolution and Employment. Cambridge University Press, Cambridge, UK.

, Griliches, Z., Hausman, J.A. (1986). "Patents and R\&D: Is There a Lag?.” International Economic Review 27, 265-83.

, Van Reenen, J. (2000). “How Effective are Fiscal Incentives for R\&D? A New Review of the Evidence." Research Policy 29, 449-469.

Harhoff, D. (1998). “Are There Financing Constraints for R\&D and Investment in German Manufacturing Firms?.” Annales d'Economie et de Statistique 49/50, 421-56.

Hellmann, T. (1998). “The allocation of control rights in venture capital contracts." RAND Journal of Economics 29, 57-76.

, Puri, M. (2000). “The interaction between product market and financing strategy: the role of venture capital.” Review of Financial Studies 13, 959-84.

Himmelberg, C.P., Petersen, B.C. (1994). "R\&D and Internal Finance: A Panel Study of Small Firms in High-Tech Industries." Review of Economics and Statistics 76, 38-51.

Hochberg, Y. (2005). Venture capital and corporate governance in the newly public firm. Unpublished working paper, Northwestern University. 
Hsu, D. (2004). “What do entrepreneurs pay for venture capital affiliation?.” Journal of Finance 59, $1805-44$.

Irwin, D., Klenow, P. (1996). "High tech R\&D subsidies: estimating the effects of Sematech." Journal of International Economics 40, 323-44.

Jeng, L., Wells, P. (2000). “The determinants of venture funding: evidence across countries.” Journal of Corporate Finance 6, 241-89.

Jensen, M.C., Meckling, W. (1976). "Theory of the Firm: Managerial Behavior, Agency Costs, and Ownership Structure.” Journal of Financial Economics 3, 305-60.

Johnson, M.S., Rao, R.P. (1997). “The Impact of Antitakeover Amendments on Corporate Financial Performance.” Financial Review 32(4), 659-89.

Jones, C., Rhodes-Kropf, M. (2003). "The price of diversifiable risk in VC and private equity." Working paper, Columbia University.

Kaplan, S., Schoar, A. (2005). "Private equity performance: returns, persistence, and capital.” Journal of Finance 60, 1791-823.

, Strömberg, P. (2003). "Financial contract theory meets the real world: an empirical analysis of venture capital contracts.” Review of Economic Studies 70, 281-315.

, Zingales, L. (1997). “Do Investment-Cash Flow Sensitivities Provide Useful Measures of Financing Constraints?” Quarterly Journal of Economics 112, 169-215.

Karaomerliolu, D.C., Jacobsson, S. (1999). “The Swedish Venture Capital Industry - An Infant, Adolescent, or Grown-up?.” Chalmers Institute of Technology, Goteborg, Sweden.

Kortum, S., Lerner, J. (2000). “Assessing the contribution of venture capital to innovation.” RAND Journal of Economics 31, 674-92.

Kraus, T. (2002). "Underpricing of IPOs and the certification role of venture capitalists: evidence from Germany’s Neuer Markt. Working paper, University of Munich. 
Lach, S., Schankerman, M. (1988). "Dynamics of R\&D and Investment in the Scientific Sector." Journal of Political Economy 97(4), 880-904.

Landier, A. (2006). Entrepreneurship and the Stigma of Failure. Unpublished working paper, New York University.

Leland, H.E., Pyle, D.H. (1977). "Informational Asymmetries, Financial Structure, and Financial Intermediation." Journal of Finance 32, 371-87.

Lee, P., Wahal, S. (2004). "Grandstanding, certification and the underpricing of venture capital backed IPOs." Journal of Financial Economics 73, 375-407.

Lerner, J. (2009). The Boulevard of Broken Dreams: Why Public Efforts to Boost Entrepreneurship and Venture Capital Have Failed_ and What to Do About It. Princeton University Press, Princeton. . (1999). "The Government as Venture Capitalist: The Long-run effects of the SBIR Program." Journal of Business 72, 285-318. . (1998a). “'Angel' Financing and Public Policy: An Overview.” Journal of Banking and Finance 22, 773-783.

. (1995). "Venture capitalists and the oversight of private firms." Journal of Finance 50, $301-18$. . (1994b). "Venture capitalists and the decision to go public." Journal of Financial Economics 35, 293-316.

. (1994a). "The syndication of venture capital investments." Financial Management 23, $16-27$. , Sorensen, M., Stromberg, P. (2008). "Private equity and long-run investment: The case of innovation.” Working paper no. 14623, National Bureau of Economic Research.

Levin, R.C., Klevorick, A.K., Nelson, R.R., Winter, S.G. (1987). “Appropriating the Returns from Industrial Research and Development.” Brookings Papers on Economic Activity 1987(3), 783-832. 
Majumdar, S.K., Nagarajan, A. (1997). "The Impact of Changing Stock Ownership Patterns in the United States: Theoretical Implications and Some Evidence.” Revue d'Economie Industrielle 82, $39-54$.

Mansfield, E., Schwartz, M., Wagner, S. (1981). "Imitation Costs and Patents: An Empirical Study." Economic Journal 91, 907-918.

Marx, L. (1994). "Negotiation and renegotiation of venture capital contracts." Working paper, University of Rochester.

Megginson, W., Weiss, K. (1991). "Venture capital certification in initial public offerings.” Journal of Finance 46, 879-93.

Miller, M.H., Modigliani, F. (1961). "Dividend Policy, Growth, and the Valuation of Shares." Journal of Business 34, 411-33.

Modigliani, F., Miller, M.H. (1958). "The Cost of Capital, Corporation Finance and the Theory of Investment." American Economic Review 48, 261-97.

Mollica, M., Zingales, L. (2007). "The impact of venture capital on innovation and the creation of new business." Unpublished working paper, Univeristy of Chicago.

Mulkay, B., Hall, B.H., Mairesse, J. (2001). "Investment and R\&D in France and in the United States.” In: Deutsche Bundesbank (Ed.), Investing Today for the World of Tomorrow. Springer Verlag.

Nelson, R.R. (1959). “The Simple Economics of Basic Scientific Research.” Journal of Political Economy 49, 297-306.

OECD. (1995). Venture Capital in OECD Countries. Organization for Economic Cooperation and Devlopement, Paris.

Opler, T.C., Titman, S. (1994). "Financial Distress and Corporate Performance." Journal of Finance 49(3), 1015-40. 
(1993). "The Determinants of Leveraged Buyout Activity: Free Cash Flow vs. Financial Distress Costs." Journal of Finance 48(5), 1985-99.

Poterba, J. (1989). "Venture capital and capital gains taxation." In: Summer, L. (Ed.), Tax Policy and the Economy. MIT Press, Cambridge, MA.

Poterba, J. (1987). "How burdensome are capital gains taxes? Evidence from the United States." Journal of Public Economics 33, 157-72.

Pugh, W.N., Jahera, Jr., J.S., Oswald, S. (1999). "ESOPs, Takeover Protection, and Corporate Decision Making." Journal of Economics and Finance 23(2), 170-83.

Romer, P.M. (1986). "Increasing Returns and Long Run Growth.” Journal of Political Economy 94(5), 1002-1037.

Sahlman, W. (1990). "The structure and governance of venture capital organizations." Journal of Financial Economics 27, 473-524.

Sand Hill Econometrics (2009). "Benchmarking the Returns to Venture," available at http://www.sandhillecon.com/pdf/SandHillWhitePaper.pdf

Scherer, F.M. (1998). “The Size Distribution of Profits from Innovation.” Annales d'Economie et de Statistique 49/50, 495-516.

Schumpeter, J. (1942). Capitalism, Socialism, and Democracy. Harper and Row (reprinted 1960), New York.

Szewczyk, S.H., Tsetsekos, G.P., Zantout, Z.Z. (1996). "The Valuation of Corporate R\&D Expenditures: Evidence from Investment Opportunities and Free Cash Flow.” Financial Management 25(1), 105-10.

Wallsten. S. (2000). "The effects of government-industry R\&D programs on private R\&D: the case of the Small Business Innovation Research program“. RAND Journal of Economics 31, 82-100. 
Williamson, O.E. (1988). “Corporate Finance and Corporate Governance.” Journal of Finance 43, 56791.

Zantout, Z.Z. (1997). “A Test of the Debt Monitoring Hypothesis: The Case of Corporate R\&D Expenditures." Financial Review 32(1), 21-48. 
Figure 1

Unconstrained Firm

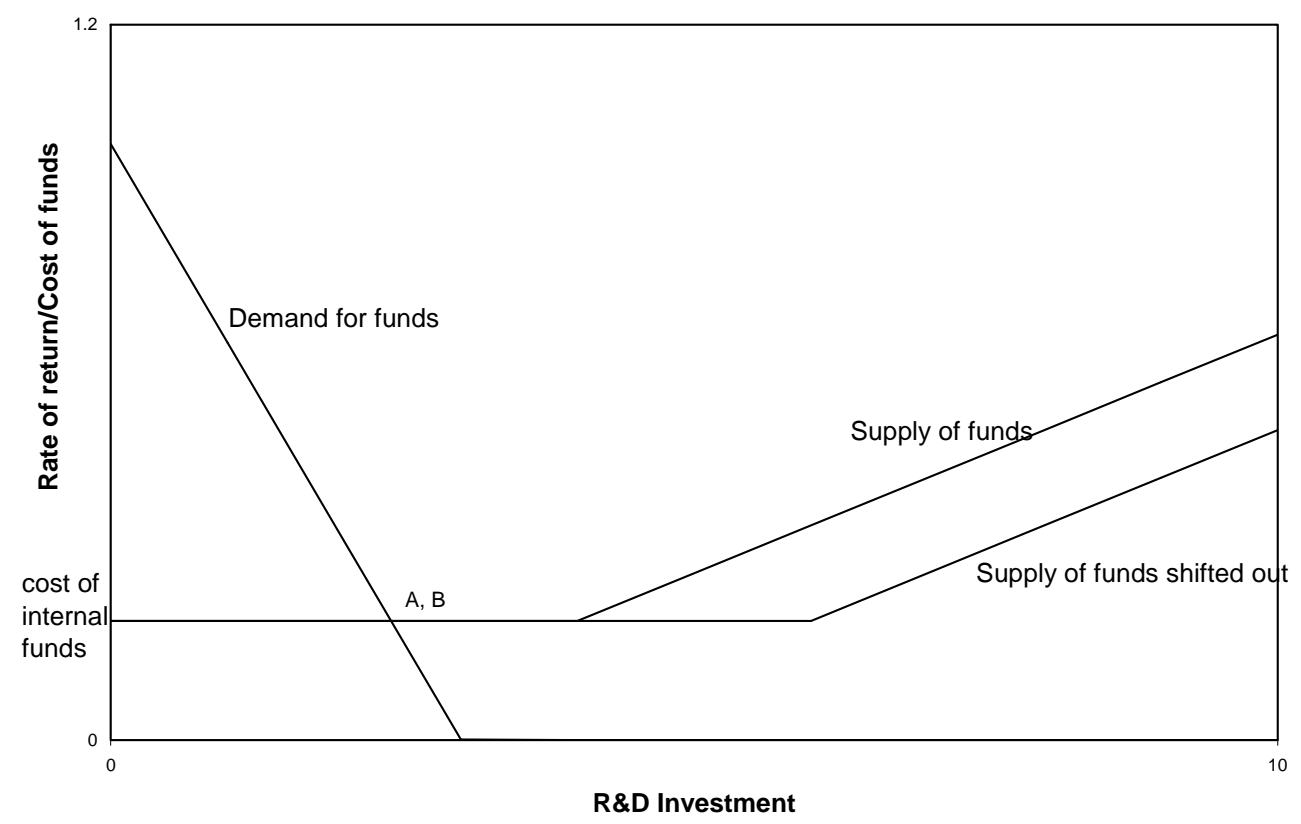

Figure 2

Constrained Firm

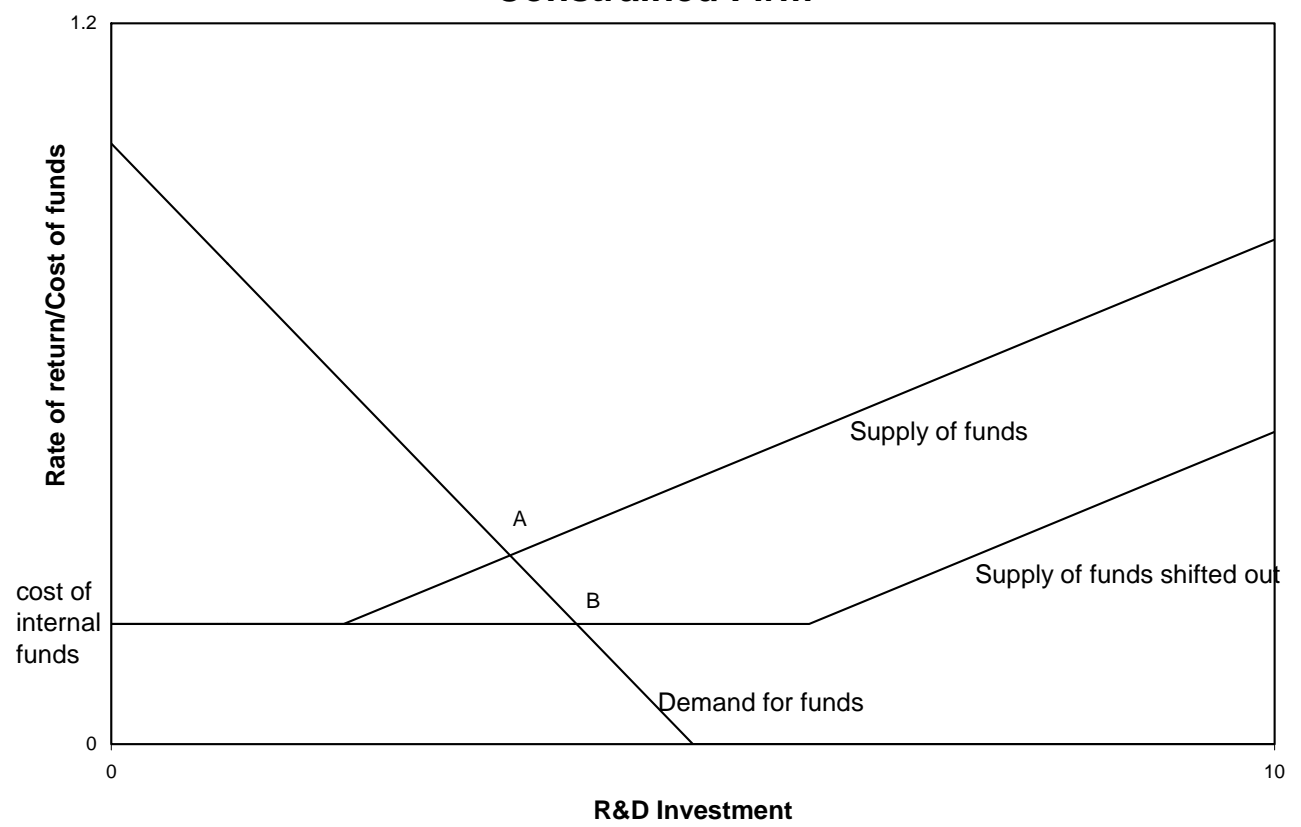


Figure 3

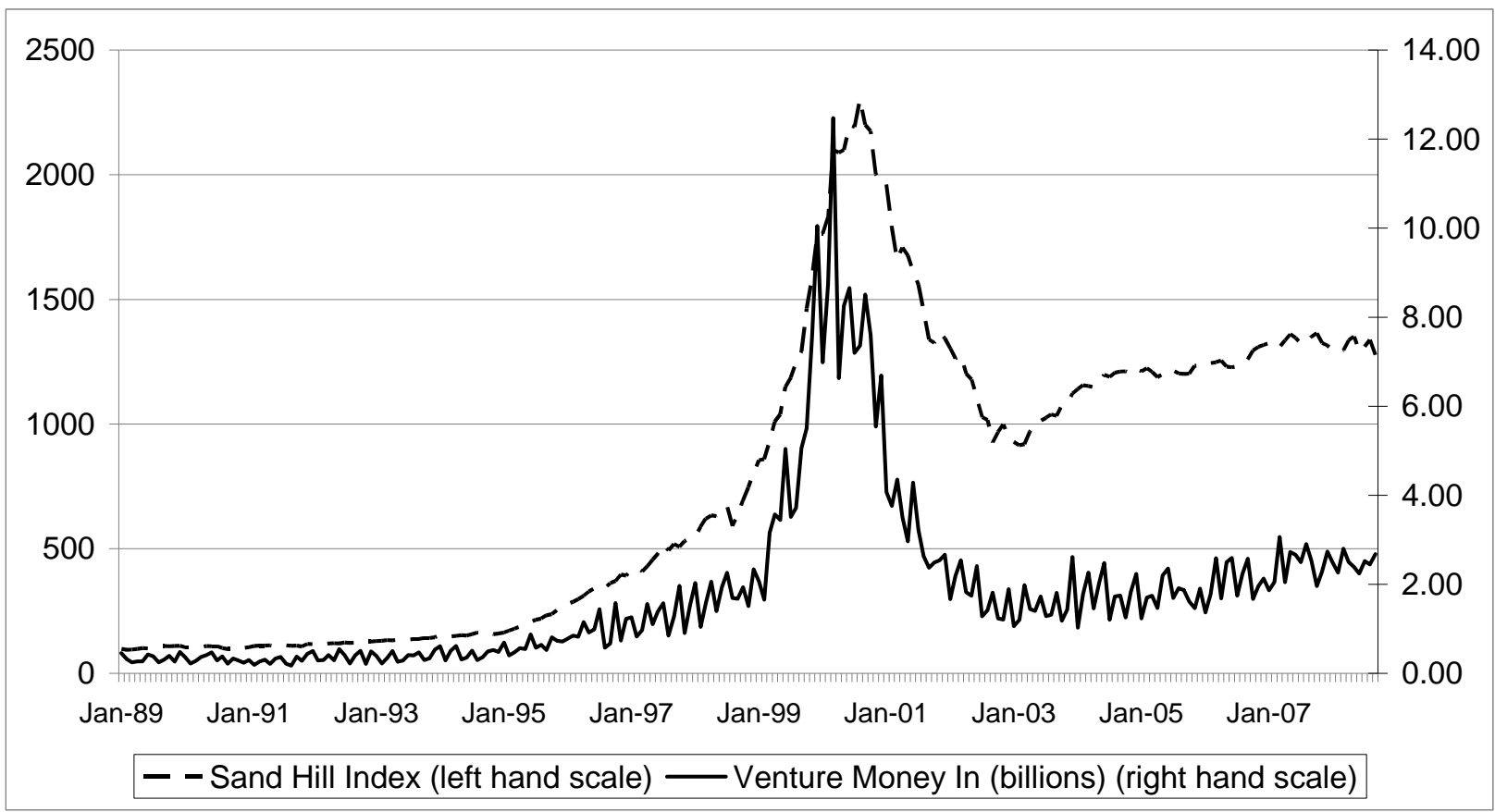

Source: Sand Hill Econometrics website (2009)

Figure 4

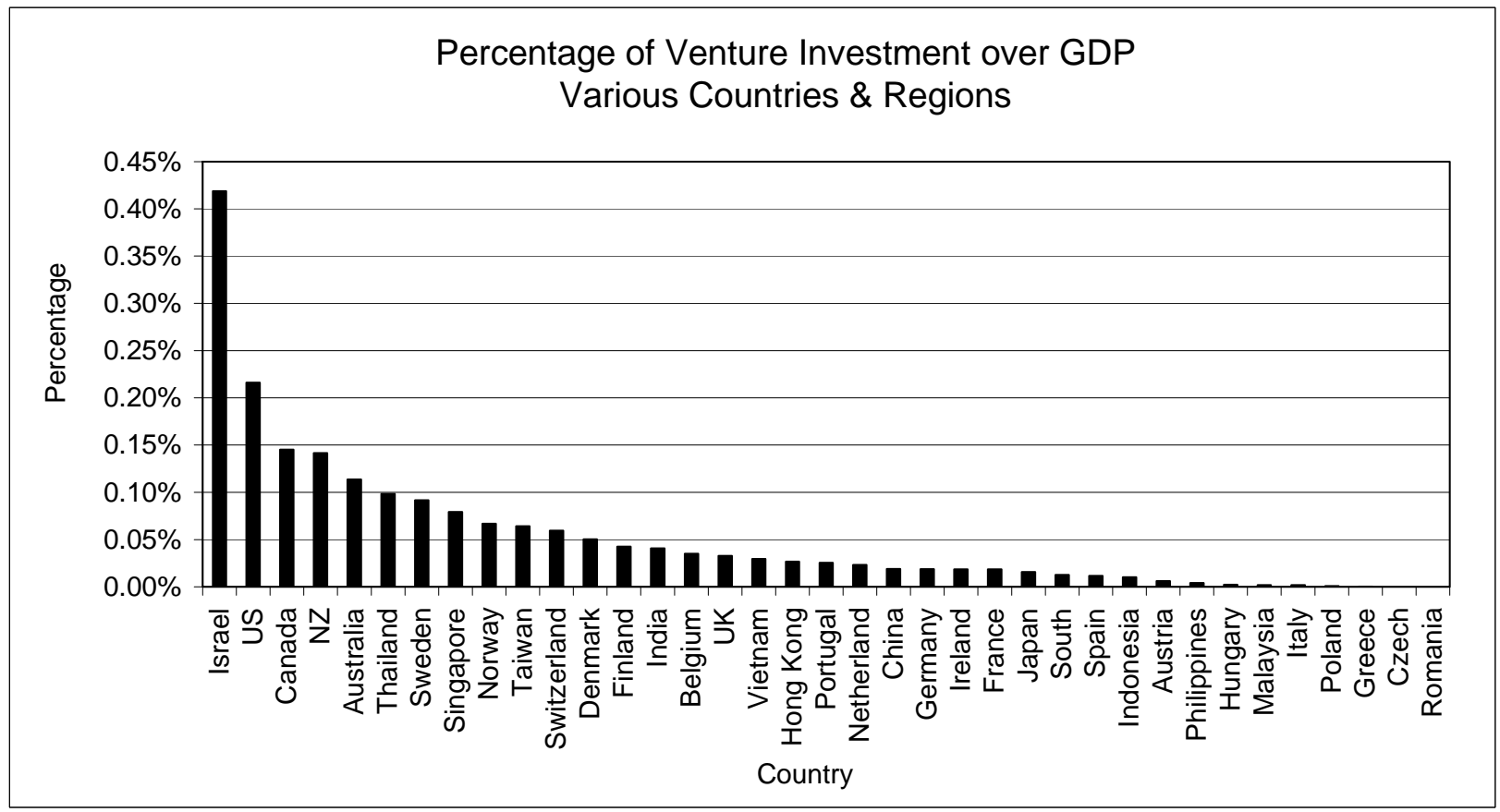




\section{Figure 5}

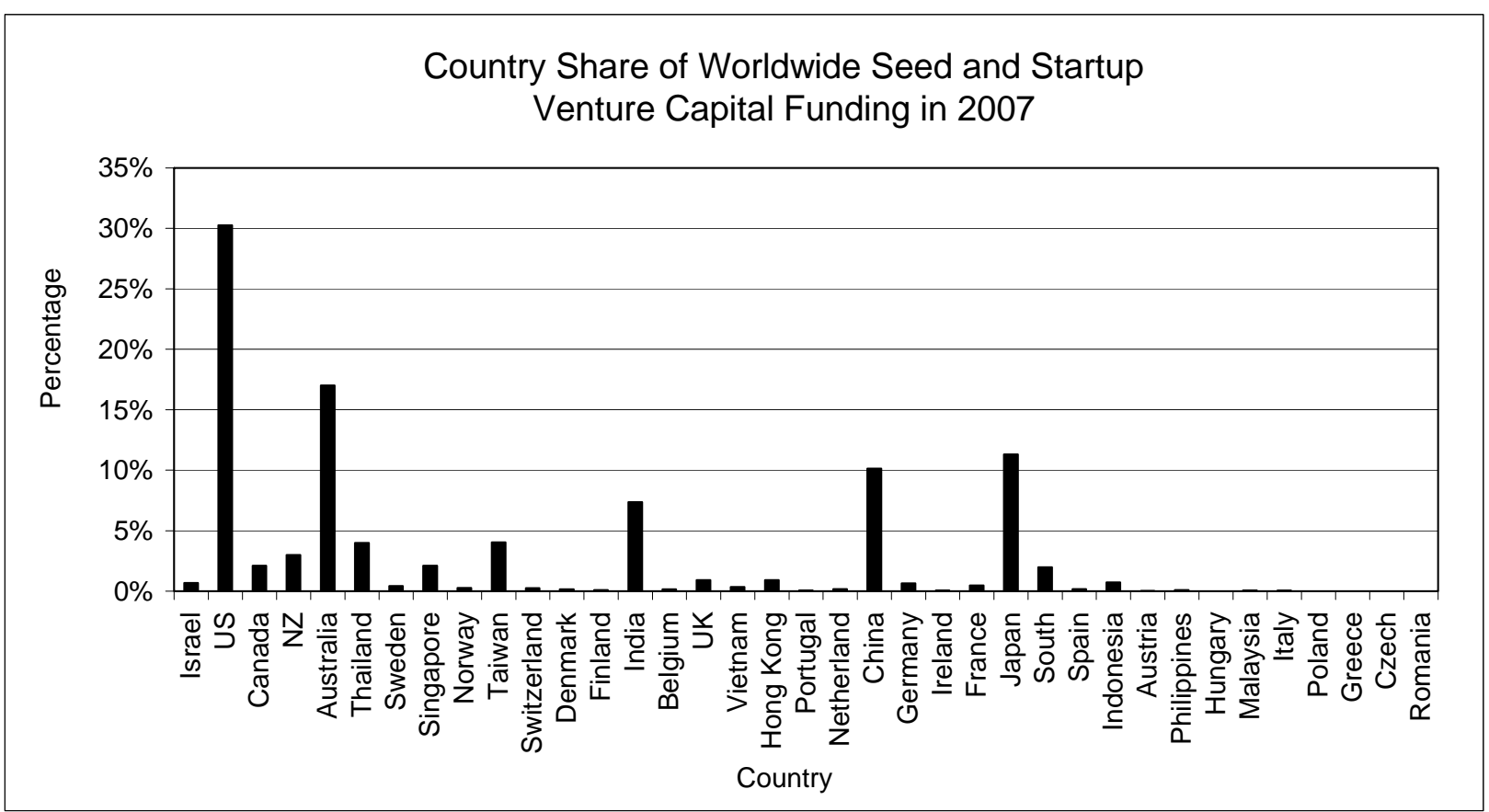

